\title{
Modeling secondary organic aerosol formation from isoprene oxidation under dry and humid conditions
}

\author{
F. Couvidat and C. Seigneur \\ CEREA, Joint Laboratory École des Ponts ParisTech/EDF R\&D, Université Paris-Est, 77455 Marne la Vallée, France
}

Received: 22 July 2010 - Published in Atmos. Chem. Phys. Discuss.: 30 August 2010

Revised: 1 December 2010 - Accepted: 14 January 2011 - Published: 31 January 2011

\begin{abstract}
A new model for the formation of secondary organic aerosol (SOA) from isoprene was developed. This model uses surrogate molecular species (hydroxyhydroperoxides, tetrols, methylglyceric acid, organic nitrates) to represent SOA formation. The development of this model used available experimental data on yields and molecular composition of SOA from isoprene and methacrolein oxidation. This model reproduces the amount of particles measured in smog chambers under both low- $\mathrm{NO}_{\mathrm{x}}$ and high- $\mathrm{NO}_{\mathrm{x}}$ conditions. Under low- $\mathrm{NO}_{\mathrm{x}}$ conditions, the model reproduces the transitional formation of hydroxy-hydroperoxides particles, which are photolyzed and lead to SOA mass decrease after reaching a maximum. Under high- $\mathrm{NO}_{\mathrm{x}}$ conditions, particles are assumed to be formed mostly from the photo-oxidation of a PAN-type molecule derived from methacrolein (MPAN). This model successfully reproduces the complex $\mathrm{NO}_{\mathrm{x}}$-dependence of isoprene oxidation and suggests a possible yield increase under some high- $\mathrm{NO}_{\mathrm{x}}$ conditions. Experimental data correspond to dry conditions $(\mathrm{RH}<10 \%)$. However, particles formed from isoprene are expected to be highly hydrophilic, and isoprene oxidation products would likely partition between an aqueous phase and the gas phase at high humidity in the atmosphere. The model was extended to take into account the hydrophilic properties of SOA, which are relevant under atmospheric conditions, and investigate the effect of particulate liquid water on SOA formation. An important increase in SOA mass was estimated for humid conditions due to the hydrophilic properties. Experiments under high relative humidity conditions should be conducted to confirm the results of this study, which have implications for SOA modeling.
\end{abstract}

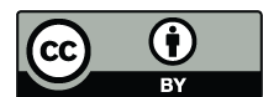

Correspondence to: F. Couvidat (couvidaf@cerea.enpc.fr)

\section{Introduction}

Atmospheric fine particles are known to have effects on health, atmospheric visibility, materials and climate. Among those particles, particulate organic matter (POM) represents a large fraction of the particulate mass, typically between 20 and 60\% (Kanakidou et al., 2005; Yu et al., 2007; Zhang et al., 2007a). Those particles are either primary (directly emitted as particles) or secondary (particles formed by chemical reactions in the atmosphere). In the latter case, secondary organic aerosols (SOA) are formed by the gas-toparticle partitioning of the oxidation products of volatile organic compounds (VOCs). VOCs are emitted by both anthropogenic and biogenic sources. However, SOA formation is poorly understood due to the numerous and complex chemical phenomena involved (successive VOC oxidation steps, $\mathrm{NO}_{\mathrm{x}}$ chemistry, compounds partitioning between several phases, SOA degradation, interactions between compounds in the particle, oligomerization).

The complexity of SOA formation makes chemical modeling of particulate matter (PM) difficult. To model SOA formation, most air quality models use simple parameterizations based on yields estimated from smog chamber measurements conducted under specific conditions, which can be different from atmospheric conditions (for example, oxidation under dry conditions). Those parameterizations rarely represent the effects of the $\mathrm{NO}_{\mathrm{x}}$ level or oligomerization, whereas those effects have been shown to greatly affect the level of SOA predicted (e.g. Ng et al., 2007a,b; Pun and Seigneur, 2007). Therefore, it is necessary to develop a parameterization that gathers all those phenomena.

Isoprene (2-methylbutadiene) is the biogenic VOC, which has the largest emission rate of all the non-methane VOCs, estimated at $600 \mathrm{Tg} \mathrm{yr}^{-1}$ (Guenther et al., 2006). Until recently, isoprene was believed not to be a major SOA precursor, despite its large emission flux, due in part to the high volatility of its first generation oxidation products such as

Published by Copernicus Publications on behalf of the European Geosciences Union. 
methacrolein and methyl vinyl ketone (Pandis et al., 1991). Furthermore, some smog chamber studies initially showed that no significant aerosol growth was observed from isoprene photooxidation under high- $\mathrm{NO}_{\mathrm{x}}$ conditions (Pandis et al., 1991). However, during field studies in Amazonia, compounds like tetrols with the same carbon skeleton as isoprene were identified (Claeys et al., 2004; Edney et al., 2005), suggesting that isoprene could in fact contribute to SOA formation. SOA formation was then confirmed by several chamber studies and has been intensively investigated (Kroll et al., 2006; Surratt et al., 2006; Ng et al., 2008; Carlton et al., 2009; Jang et al., 2002).

Therefore, it is important to take isoprene-SOA into account in air quality modeling. Chamber experiments led to the identification of species composing isoprene SOA like tetrols and methylglyceric acid (Surratt et al., 2006; Kleindienst et al., 2009). As those products are rather small organic molecules (number of carbon atoms $\leq 5$ ) and with numerous functional groups, they are expected to be highly hydrophilic. Then, those compounds would likely partition between an aqueous phase and the gas phase at high humidity in the atmosphere. It has been shown that taking into account the hydrophilic properties of isoprene SOA increases greatly the amount of SOA formed (Pun, 2008), whereas the parameterization of Zhang et al. (2007b) used currently in most air quality models does not take those effects into account.

The objective of this work is to develop a new model for the formation of SOA from isoprene, which takes into account $\mathrm{NO}_{\mathrm{x}}$ chemistry, the hydrophilic properties of molecular species and oligomerization. First, a model is developed based on results from experiments conducted under dry conditions. Next, the model is extended to humid conditions by taking into account gas-aqueous phase partitioning.

\section{Model development}

\subsection{Method}

To develop the model for SOA formation from isoprene oxidation, the experimental results of Kroll et al. (2006) and Surratt et al. (2006) were used. Those experiments were done in the Caltech experimental chamber under both low- $\mathrm{NO}_{\mathrm{x}}$ and high- $\mathrm{NO}_{\mathrm{x}}$ conditions. A complete description of the facility is given by Cocker III et al. (2001). The gas-phase chemistry was simulated with RACM2 (Goliff and Stockwell, 2008), which includes a mechanism for isoprene oxidation. This mechanism has been shown to perform well for oxidant formation (Kim et al., 2009). The mechanism was modified to take into account the formation of the surrogate species to represent SOA formation as described below. The ROS2 algorithm (Verwer et al., 1999) was used to solve the chemical kinetic equations.

The experiments of Kroll et al. (2006) and Surratt et al. (2006) used blacklights, which emit in the ultraviolet be- tween 300 and $400 \mathrm{~nm}$ with a maximum at $354 \mathrm{~nm}$ (Kroll et al., 2006). Under those conditions, nitrate radical $\left(\mathrm{NO}_{3}\right)$ and ozone $\left(\mathrm{O}_{3}\right)$ photolysis hardly occurs (Carter et al., 2005) and their photolysis rates are almost negligible. The rate given by Kroll et al. (2006) was used for $\mathrm{H}_{2} \mathrm{O}_{2}$ photolysis, which leads to hydroxy radical (HO) formation in the chamber. As the evolution of isoprene concentrations as a function of time was in good agreement with the isoprene degradation observed by Kroll et al. (2006), we consider that the HO concentrations are correctly simulated by the gas-phase mechanism and the impact of $\mathrm{HO}$ concentrations was not studied. The photolysis rate for $\mathrm{NO}_{2}$ photolysis was chosen so that the maximum ozone concentration matches the results from Kroll et al. (2006). $\mathrm{O}_{3}, \mathrm{NO}_{3}$ and $\mathrm{HONO}$ photolysis rates were then calculated using the photolysis rates relative to $\mathrm{NO}_{2}$ given by Carter et al. (2005).

As those experiments were done under dry conditions ( $\mathrm{RH}<10 \%$ ), partitioning between the gas phase and an organic liquid phase was assumed. The partitioning was calculated using the model of Pankow (1994a,b), which defines the absorption equilibrium constant $\left(K_{p, i}\right)$ according to Raoult's law as:

$K_{\mathrm{om}, i}=\frac{F_{i, \mathrm{om}}}{A_{i} M_{\mathrm{o}}}=\frac{760 R T}{\mathrm{MW}_{\mathrm{om}} 10^{6} \zeta_{i} p_{L, i}^{\mathrm{o}}}$

where $A_{i}$ is the gas-phase concentration of compound $i$ $\left(\mathrm{ng} \mathrm{m}^{-3}\right), F_{i, \mathrm{om}}$ is the concentration of the compound $i$ in the absorbing organic phase $\left(\mathrm{ng} \mathrm{m}^{-3}\right), M_{\mathrm{O}}$ is the absorbing organic mass concentration $\left(\mu \mathrm{g} \mathrm{m}^{-3}\right), R$ is the ideal gas constant $\left(8.206 \times 10^{-5} \mathrm{~m}^{3}\right.$ atm mol$\left.{ }^{-1} \mathrm{~K}^{-1}\right), T$ is the temperature $(K), \mathrm{MW}_{\mathrm{om}}$ is the mean molecular weight of the absorbing organic phase $\left(\mathrm{g} \mathrm{mol}^{-1}\right), \zeta_{i}$ is the activity coefficient of compound $i$ in the organic phase, and $p_{L, i}^{\mathrm{o}}$ is the saturation vapor pressure of the absorbed compound (torr). The thermodynamic model UNIFAC (UNIversal Functional group Activity Coefficient) was used to calculate activity coefficients (Fredenslund et al., 1975). The missing UNIFAC parameters (for the functional groups nitrate and hydroperoxide) were taken from Comernolle et al. (2009). An iterative method was used to calculate activity coefficients and the partitioning.

The effect of temperature was taken into account according to the Clausius-Clapeyron equation using enthalpies of vaporization. Kleindienst et al. (2009) measured the effective enthalpies of vaporization of SOA formed from isoprene oxidation for both low $-\mathrm{NO}_{\mathrm{x}}$ and high- $\mathrm{NO}_{\mathrm{x}}$ conditions. Those values were used in this study: a value of $38.4 \mathrm{~kJ} \mathrm{~mol}^{-1}$ for compounds formed under low- $\mathrm{NO}_{\mathrm{x}}$ conditions (tetrols, hydroxy-hydroperoxides) and a value of $43.2 \mathrm{~kJ} \mathrm{~mol}^{-1}$ for compounds formed under high- $\mathrm{NO}_{\mathrm{x}}$ conditions (methylglyceric acid, organic nitrates). The use of experimental effective enthalpies of vaporization instead of theoretically estimated values for specific SOA compounds is appropriate because SOA surrogates may represent a lumping of several individual compounds. 
Stoechiometric coefficients of condensable products, saturation vapor pressure (for low- $\mathrm{NO}_{\mathrm{x}}$ conditions), effective partitiong constant (for high- $\mathrm{NO}_{\mathrm{x}}$ conditions) of the different surrogate species were selected to reproduce the results of experiments. The reactions added to RACM2 for SOA formation from isoprene are listed in Table 1. The first six reactions dominate under low- $\mathrm{NO}_{\mathrm{x}}$ conditions whereas the last two reactions dominate under high- $\mathrm{NO}_{\mathrm{x}}$ conditions. Propertes of surrogate species (molecular structure, saturation vapor pressures, molar mass and enthalpies of vaporization) are listed in Table 2.

The model development for SOA formation via oxidation of isoprene by $\mathrm{NO}_{3}$ and $\mathrm{HO}$ is presented next. Although SOA formation occurs via oxidation of isoprene by $\mathrm{O}_{3}$ (Kamens et al., 1982; Kleindienst et al., 2007; Nguyen et al., 2010), this pathway was not taken into account here because of insufficient quantitative and mechanism information to develop a model at this point.

\subsection{Oxidation of isoprene by $\mathrm{NO}_{3}$}

The results of $\mathrm{Ng}$ et al. (2008) were used to model oxidation of isoprene by $\mathrm{NO}_{3}$. In their study, a $\mathrm{C}_{5}$-hydroxy-trinitrate $\left(\mathrm{C}_{5} \mathrm{H}_{9} \mathrm{~N}_{3} \mathrm{O}_{10}\right)$ compound (structure of the compound shown in Table 2) was found to be predominant in the "typical experiment" of $\mathrm{Ng}$ et al. (2008) (experiment relevant to atmospheric conditions). Therefore, it was used as a surrogate compound for $\mathrm{SOA}$ formation for oxidation by $\mathrm{NO}_{3}$.

Isoprene reacts with $\mathrm{NO}_{3}$ to form the surrogate ISON in RACM2 (which groups all compounds formed from the oxidation of isoprene with $\mathrm{NO}_{3}$ ) by this reaction:

$\mathrm{ISO}+\mathrm{NO}_{3} \Rightarrow \mathrm{ISON}$

(with a kinetic constant $k=6.61 \times$ $10^{-13}$ molecule ${ }^{-1} \mathrm{~cm}^{3} \mathrm{~s}^{-1}$ ). However, there is no oxidation of this compound by $\mathrm{NO}_{3}$ in RACM2. The following reaction was added to $\mathrm{RACM} 2$ to take into account the formation of $\mathrm{C}_{5}$-hydroxy-trinitrate:

$\mathrm{ISON}+\mathrm{NO}_{3} \Rightarrow \ldots \Rightarrow \alpha_{\mathrm{NO} 3} \mathrm{C}_{5} \mathrm{H}_{9} \mathrm{~N}_{3} \mathrm{O}_{10}$

where $\alpha_{\mathrm{NO} 3}$ is the stoichiometric coefficient of the $\mathrm{C}_{5}$-hydroxy-trinitrate. A kinetic constant of $7.0 \times 10^{-14}$ molecule ${ }^{-1} \mathrm{~cm}^{3} \mathrm{~s}^{-1}$ was taken from Rollins et al. (2009).

The method of Odum et al. (1996) with aerosol yields was used by $\mathrm{Ng}$ et al. (2008) with two surrogate compounds to estimate SOA formation parameters. Here, the same method was used but with only one surrogate compound because one surrogate compound is sufficient to reproduce the results of $\mathrm{Ng}$ et al. (2008) as shown in Fig. 1. A stoichiometric coefficient $\alpha_{\mathrm{NO} 3}$ of 0.074 was estimated with a saturation vapor pressure of $1.12 \times 10^{-6}$ torr.

It should be noted that the formation of $\mathrm{C}_{5} \mathrm{H}_{9} \mathrm{~N}_{3} \mathrm{O}_{10}$ may be a minor pathway for SOA formation in the atmosphere because there is probably not enough $\mathrm{NO}_{3}$ in the atmosphere

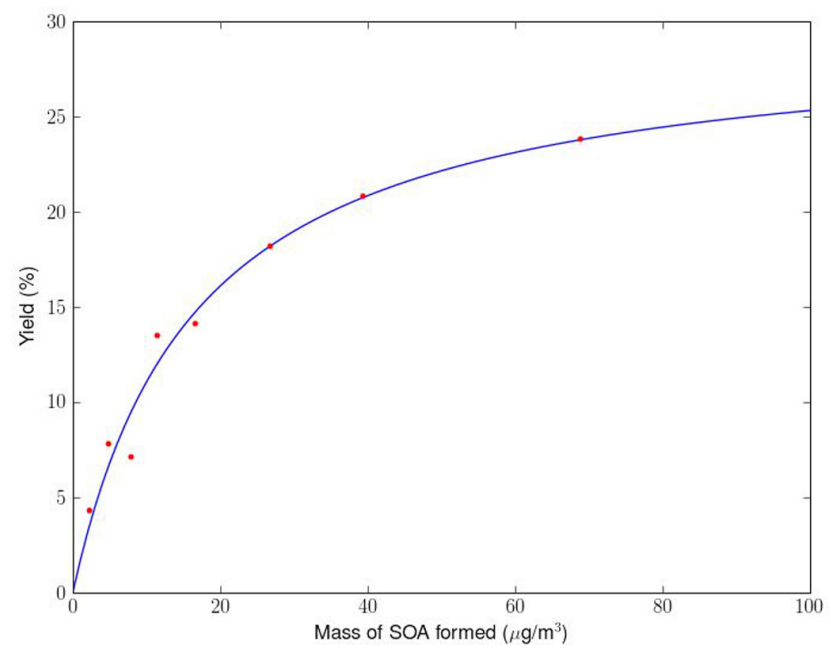

Fig. 1. SOA yield data and yield curve for isoprene- $\mathrm{NO}_{3}$ reaction using one surrogate compound.

to form much $\mathrm{C}_{5}$-hydroxy-trinitrate $\left(\mathrm{C}_{5}\right.$-dihydroxy-dinitrate is more likely). Reaction R2 could then overestimate SOA formation from ISON oxidation. However, this reaction could be used to deduce whether or not oxidation of isoprene by $\mathrm{NO}_{3}$ can lead to a significant quantity of SOA. In this study, this reaction was used to make sure that $\mathrm{NO}_{3}$ does not contribute significantly to SOA formation in environmental chambers.

\subsection{Oxidation of isoprene by HO: formation of methyl-tetrols and hydroxy-hydroperoxides under low-NO $\mathrm{N}_{\mathrm{x}}$ conditions}

Methyl-tetrols and hydroxy-hydroperoxides are expected to be the two main compounds formed from the photooxidation of isoprene under low- $\mathrm{NO}_{\mathrm{x}}$ conditions. Whereas tetrols have been explicitly identified in chamber experiments (Kleindienst et al., 2009), the structure of hydroxyhydroperoxides is still unknown and has not been conclusively identified (Kroll et al., 2006). Nevertheless, it is expected to be a key-component for SOA formation (Kroll et al., 2006; Surratt et al., 2006) and Surratt et al. (2006) confirmed that peroxides constitute a large fraction of SOA under low- $\mathrm{NO}_{\mathrm{x}}$ conditions. Under the conditions of Kroll et al. (2006), the $\mathrm{RO}_{2}$ (organic radical) chemistry is dominated by $\mathrm{RO}_{2}+\mathrm{HO}_{2}$ reactions. Hydroxy-hydroperoxides are expected to be formed by those reactions. In RACM2, the formation of the radical (noted ISOP) from the oxidation of isoprene by $\mathrm{HO}$ can lead to the formation of first-generation hydroxyhydroperoxides (noted ISHP) by the following chemical reactions:

$$
\begin{aligned}
& \mathrm{ISO}+\mathrm{HO} \Rightarrow \text { ISOP } \\
& \text { ISOP }+\mathrm{HO}_{2} \Rightarrow \text { ISHP }
\end{aligned}
$$


Table 1. Reactions and products added to RACM2.

\begin{tabular}{ll}
\hline Reactions & kinetic rate parameters $\left(\right.$ molecule $\left.\mathrm{cm}^{3} \mathrm{~s}^{-1}\right)$ \\
\hline ISHP $+\mathrm{HO} \Rightarrow \ldots+0.28 \mathrm{BiPER}+0.030 \mathrm{BiDER}$ & $3.0 \times 10^{-11}$ \\
$2 \mathrm{ISOP} \Rightarrow 2 \mathrm{MACR}+\mathrm{HCHO}+\mathrm{HO}_{2}+0.16 \mathrm{DIOL}$ & $2.0 \times 10^{-12}$ \\
$\mathrm{ISOP}+\mathrm{MO}_{2} \Rightarrow \ldots+0.16 \mathrm{DIOL}$ & $3.40 \times 10^{-14} \mathrm{exp}(221 / \mathrm{T})$ \\
$\mathrm{ISOP}+\mathrm{ACO}_{3} \Rightarrow \ldots+0.16 \mathrm{DIOL}$ & $8.40 \times 10^{-14} \mathrm{exp}(221 / \mathrm{T})$ \\
$\mathrm{DIOL}+\mathrm{HO} \Rightarrow 0.16 \mathrm{BiMT}+\mathrm{HO}^{*}$ & $1.30 \times 10^{-10}$ \\
$\mathrm{ISON}+\mathrm{NO}_{3} \Rightarrow 0.074 \mathrm{C}_{5} \mathrm{H}_{9} \mathrm{~N}_{3} \mathrm{O}_{10}$ & $6.61 \times 10^{-13}$ \\
$\mathrm{MPAN}+\mathrm{HO} \Rightarrow \ldots+0.063 \mathrm{BiMGA}^{-10.046 \mathrm{BiNGA}}$ & $3.20 \times 10^{-11}$ \\
\hline
\end{tabular}

* Oxidant HO is added as both reactant and product in order not to modify HO prediction by RACM2.

Table 2. Properties of the selected SOA surrogate species.

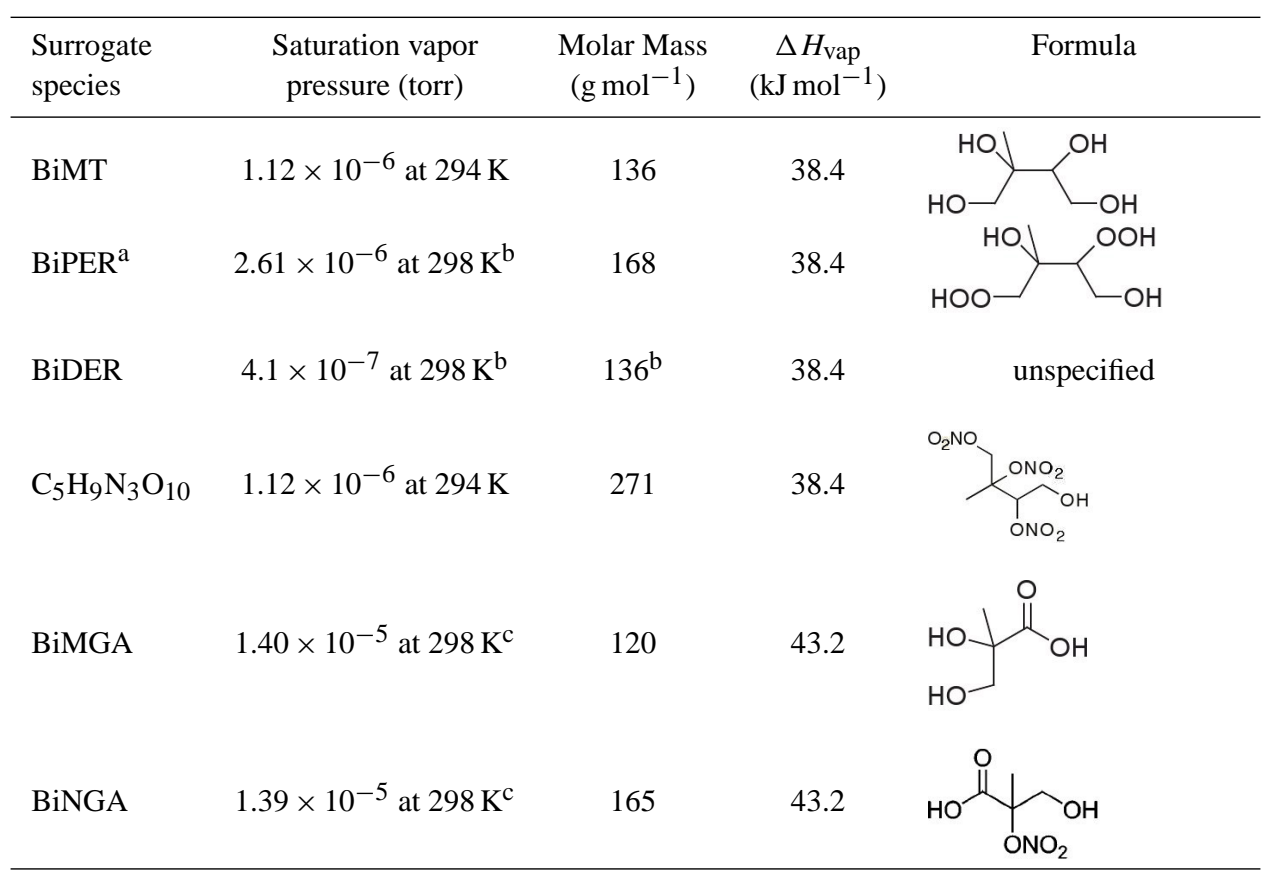

${ }^{a}$ Can undergo degradation due to photolytic reactions $\left(k_{\text {degradation }}=2.0 \times 10^{-4} \mathrm{~s}^{-1}\right)$.

b Value obtained by using tetrols as BiDER structure. Results may change with an other structure (change mainly due to different molar mass, see text).

${ }^{\mathrm{c}}$ Can undergo oligomerization. Calculated partitioning constant with this saturation vapor pressure has to be changed to take into account oligomerization with Eq. 3 . $K_{\text {oligo }}=64.2$.

However, the surrogate compound ISHP is too volatile to form SOA (the group contribution method SIMPOL.1 (Pankow and Asher, 2008) gives a saturation vapor pressure of $6.09 \times 10^{-3}$ torr). Only one of the isoprene double bonds has been oxidized to form ISHP. If hydroxy-hydroperoxides SOA are formed, it can be assumed that ISHP is a key intermediate in their formation. So, it was assumed that hydroxyhydroperoxides are formed from the oxidation of the ISHP double bond by $\mathrm{HO}$ and a subsequent $\mathrm{RO}_{2}+\mathrm{HO}_{2}$ reaction:

$\mathrm{ISHP}+\mathrm{HO} \Rightarrow \ldots \Rightarrow \ldots+\alpha \mathrm{BiPER}+\beta \mathrm{BiDER}$

where BiPER is a dihydroxy-dihydroperoxide, which may undergo photolysis, BiDER is another product with structure unknown, which is not photolyzed, $\alpha$ and $\beta$ are respec- tively the stoichiometric coefficients of BiPER and BiDER. Because of lack of data, molar mass and molecular structure of BiDER were assumed to be those of tetrols but the saturation vapor pressure was chosen to be different from the tetrol saturation vapor pressure in order to fit the experimental data (the sensitivity of the model to this assumption is investigated below). A rate constant of $3.0 \times 10^{-11}$ molecule ${ }^{-1} \mathrm{~cm}^{3} \mathrm{~s}^{-1}$ was chosen for reaction R5 (kinetics supposed similar to the kinetics of the MACR $+\mathrm{HO}$ reaction in RACM2 Goliff and Stockwell, 2008). 
After reaching a maximum, the SOA mass was observed to decrease rapidly in the experiments of Kroll et al. (2006) under low- $\mathrm{NO}_{\mathrm{x}}$ conditions. The decrease stopped immediately when the lights were turned off. It indicates that the loss is due to photolytic activity and not to wall losses. To our knowledge, rapid loss of SOA has not been observed in the photo-oxidation of another compound.

The mechanism for SOA loss has not been completly elucidated. The loss of SOA could be due to either gas-phase reactions (consumption of the partitioning compounds may drive equilibrium away from the particle phase) or particlephase reactions (Kroll et al., 2006). For example, SOA loss could be due to gas-phase reaction with $\mathrm{HO}$ or photolysis. Kroll et al. (2006) assumed that the compounds accountable for the rapid SOA loss may be organic hydroperoxides as this loss is only seen under low- $\mathrm{NO}_{\mathrm{x}}$ conditions. The pathway by which this SOA loss occurs should be clarified (particlephase reaction, gas-phase reaction, photolysis) by further experimental studies.

Because of the uncertainties of the SOA loss mechanism, modeling the loss by a global BiPER degradation kinetics (degradation into both particulate and gas phases) was chosen:

\section{$\mathrm{BiPER} \Rightarrow$ Unknown Products}

Tetrols are assumed to be formed from the oxidation of diols which can be formed from $\mathrm{RO}_{2}+\mathrm{RO}_{2}$ reactions. Under low- $\mathrm{NO}_{\mathrm{x}}$ conditions, $\mathrm{RO}_{2}+\mathrm{RO}_{2}$ reactions become predominant when concentrations of isoprene become high but can contribute slightly to SOA formation in Kroll et al. (2006). RACM2 does not take into account the diol formation from isoprene. However, Ruppert and Becker (2000) give a yield for diol formation between $7.1 \%$ and $9.3 \%$. A yield of $8.0 \%$ was assumed here. Based on data of Ruppert and Becker (2000), a rate constant for the oxidation of diols by HO of $13.0 \times 10^{-11}$ molecule ${ }^{-1} \mathrm{~cm}^{3} \mathrm{~s}^{-1}$ was chosen. Under the conditions of Ruppert and Becker (2000), diols (noted here DIOL) can be expected to be formed from an ISOP + ISOP reaction, as follows:

$2 \mathrm{ISOP} \Rightarrow 2 \mathrm{MACR}+\mathrm{HCHO}+\mathrm{HO}_{2}+0.16 \mathrm{DIOL}$

The ISOP + ISOP reaction has been taken from Pöschl et al. (2000) and DIOL formation was added to this reaction (the yield was multiplied by two because two radicals from isoprene react in this reaction). ISOP can also be oxidized by radicals $\mathrm{MO}_{2}$ and $\mathrm{ACO}_{3}$. The following reactions have been added to RACM2:

$\mathrm{ISOP}+\mathrm{MO}_{2} \Rightarrow \ldots+0.16 \mathrm{DIOL}$

$\mathrm{ISOP}+\mathrm{ACO}_{3} \Rightarrow \ldots+0.16 \mathrm{DIOL}$

$\mathrm{DIOL}+\mathrm{HO} \Rightarrow \gamma \mathrm{BiMT}+\mathrm{HO}$

where BiMT is the surrogate compound for tetrols and $\gamma$ is the corresponding stoichiometric coefficient of BiMT. The

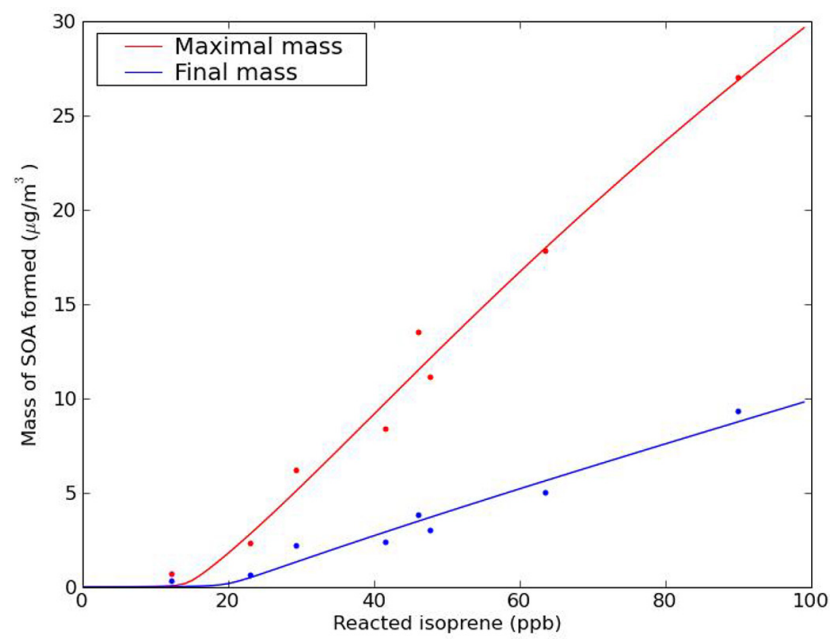

Fig. 2. SOA growth versus isoprene reacted. Dots correspond to measurements from Kroll et al. (2006). Lines correspond to results from the model for $T=298 \mathrm{~K}$.

group contribution method SIMPOL.1 gives similar saturation vapor pressures for tetrols and $\mathrm{C}_{5}$-hydroxy-trinitrate. Accordingly, the saturation vapor pressure of tetrols was taken identical to that of $\mathrm{C}_{5}$-hydroxy-trinitrate. A value for $\gamma$ of 0.16 was used (assuming that the second oxidation has the same yield as the oxidation of the first double bond).

In the atmosphere, concentrations of ISOP are not typically sufficient for reaction R7 to be dominant. Inside environmental chambers, reactions $\mathrm{R} 8$ and $\mathrm{R} 9$ probably do not produce high quantity of DIOL due to the low concentrations of radicals $\mathrm{MO}_{2}$ and $\mathrm{ACO}_{3}$. However, those radicals are likely to be in higher concentrations in the atmosphere and BiMT could be formed by this pathway.

The stoichiometric coefficients $\alpha$ and $\beta$, the degradation rate of BiPER (R6) and the saturation vapor pressures of BiPER and BiDER were selected to minimize the error between modeled and experimental results by a least square method for both maximal and final mass of SOA. A mean temperature of $25^{\circ} \mathrm{C}$ was assumed. However, to be able to solve the system, one of the parameters has to be set. According to Kroll et al. (2006), the SOA loss is about $0.006-0.018 \mathrm{~min}^{-1}$. A mean value of $0.012 \mathrm{~min}^{-1}$ was then taken for reaction R6. Optimization gives the values of the parameters presented in Table 3. Results of the comparison between modeled and measured SOA formation are shown in Table 4 and Fig. 2. Figure 3a shows the results of a simulation for $63.6 \mathrm{ppb}$ of isoprene.

The model reproduces well the results from Kroll et al. (2006) but there are still uncertainties, in particular in the mechanism for SOA degradation and in the values for the yield and the saturation vapor pressure of methyl-tetrols. Under the conditions of Kroll et al. (2006), tetrols only represent a small part of SOA (simulation for the oxidation of 
(a) Initial concentration of isoprene: $63.6 \mathrm{ppb}$

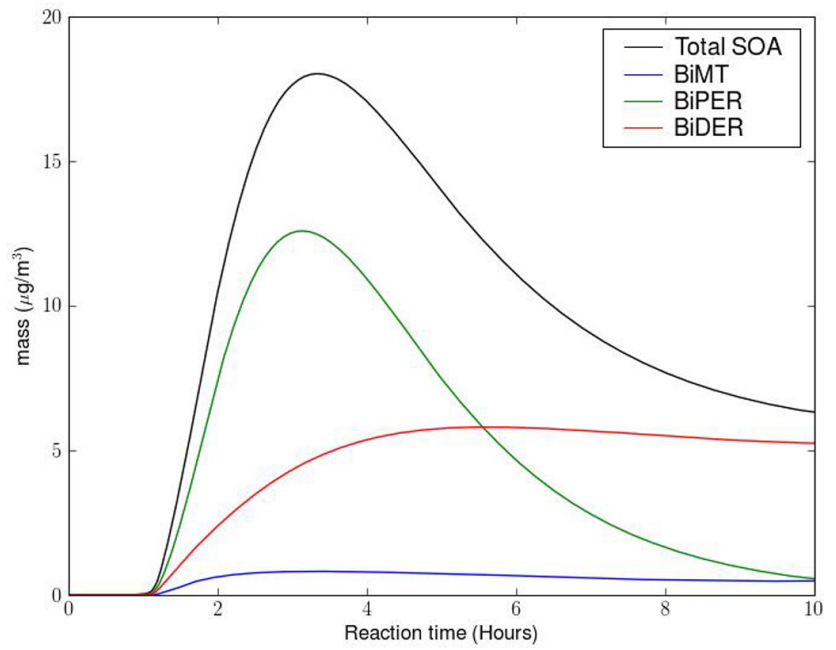

(b) Initial concentration of isoprene: $500 \mathrm{ppb}$

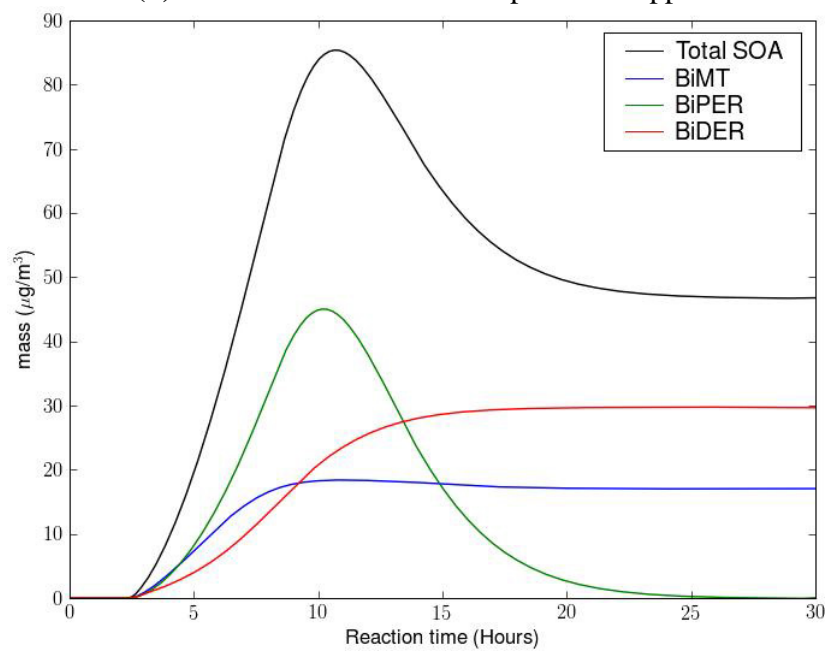

Fig. 3. Evolution of the calculated mass of SOA formed from isoprene photooxidation as a function of time at $T=298 \mathrm{~K}$ (a) for an initial isoprene concentration of $63.6 \mathrm{ppb}$ (b) for an initial isoprene concentration of $500 \mathrm{ppb}$.

$63.6 \mathrm{ppb}$ of isoprene gives $8 \%$ of tetrols). But tetrols would represent a larger fraction of SOA with a larger quantity of oxidized isoprene because the ISOP + ISOP reaction would then be competitive with the ISOP $+\mathrm{HO}_{2}$ reaction. This is confirmed by a simulation done with $500 \mathrm{ppb}$ where tetrols represent about $40 \%$ of SOA formed (Fig. 3b).

\subsection{Oxidation of isoprene by HO: formation of methyl-glyceric acid under high-NO $\mathrm{N}_{\mathrm{x}}$ conditions}

Under high- $\mathrm{NO}_{\mathrm{x}}$ conditions, Surratt et al. (2006) showed that methyl-glyceric acid (MGA) and its nitrate derivative can oligomerize and form substantial amount of SOA. Recent studies showed that MGA is formed from the oxidation of
Table 3. Values of the optimized parameters used for low- $\mathrm{NO}_{\mathrm{x}}$ conditions at $298 \mathrm{~K}$.

\begin{tabular}{lr}
\hline Parameter & Value \\
\hline$\alpha$ & 0.28 \\
$\beta$ & 0.030 \\
BiPER degradation & $2.0 \times 10^{-4} \mathrm{~s}^{-1}$ \\
BiPER saturation vapor pressure & $2.6 \times 10^{-6}$ torr \\
BiDER saturation vapor pressure & $4.1 \times 10^{-7}$ torr \\
\hline
\end{tabular}

MPAN (PAN-type molecule derived from the oxidation of methacrolein) (Surratt et al., 2010; Chan et al., 2010) and that MGA strongly depends on the initial $\left[\mathrm{NO}_{2}\right] /[\mathrm{NO}]$ ratio (because MPAN formation is favored under high $\mathrm{NO}_{2}$ conditions).

To model SOA formation under high- $\mathrm{NO}_{\mathrm{x}}$ conditions, we assumed that SOA formation comes mainly from MGA and its nitrate derivative formation via MPAN oxidation. Currently, there is not enough information to distinguish MGA formation from its nitrate derivative formation in the model. However, experiments by Surratt et al. (2006) show that the two molecules are formed in equivalent quantities when isoprene is oxidized under high- $\mathrm{NO}_{\mathrm{x}}$ conditions. We assumed that MPAN oxidation leads to the same overall mass (particle + gas) of MGA and its nitrate derivative. It means that there is 1.375 (molecular weight ratio of the two compounds) times as much MGA as nitrate:

$\mathrm{MPAN}+\mathrm{HO} \Rightarrow \ldots+1.375 \lambda \mathrm{BiMGA}+\lambda \mathrm{BiNGA}$

where BiMGA represents MGA, BiNGA represents its nitrate derivative and $\lambda$ is the stoichiometric coefficient for BiNGA. However, when methacrolein is directly oxidized, a higher quantity of nitrate derivative is formed. This fact could be due to faster MPAN formation when methacrolein is directly oxidized: more $\mathrm{NO}_{\mathrm{x}}$ is available to react with MPAN, which leads to higher nitrate derivative concentrations. When isoprene is oxidized, methacrolein is formed first and MPAN formation occurs latter in the oxidation process. Then, there is more time for $\mathrm{NO}_{\mathrm{x}}$ to be consumed to form $\mathrm{HNO}_{3}$. As the nitrate derivative has a higher molecular weight than MGA and a priori a similar saturation vapor pressure, the hypothesis made could lead to underestimation of the SOA mass in environmental chamber under some conditions.

Oligomerization can impact strongly the formation of SOA (e.g. Gao et al., 2004; Jang et al., 2005; Liggio et al., 2005). It is then important to take it into account. To take into account oligomerization, a simple parameterization was developed:

$K_{\text {oligo }}=\frac{A_{\text {oligomer }}}{A_{\text {monomer }}}$ 
Table 4. Comparison of measured ${ }^{\mathrm{a}}$ and modeled $^{\mathrm{b}}$ SOA formation $\left(\Delta M_{\mathrm{O}}\right)$ for $\mathrm{NO}_{\mathrm{x}}$-free conditions: maximum $\Delta M_{\mathrm{O}}$ and final $\Delta M_{\mathrm{O}}$.

\begin{tabular}{lrrlr}
\hline $\begin{array}{l}\text { Initial } \\
\text { isoprene }(\mathrm{ppb})\end{array}$ & $\begin{array}{r}\text { Measured } \Delta M_{\mathrm{O}} \\
(\mathrm{max})\left(\mu \mathrm{g} \mathrm{m}^{-3}\right)\end{array}$ & $\begin{array}{r}\text { Calculated } \Delta M_{\mathrm{O}} \\
(\max )\left(\mu \mathrm{g} \mathrm{m}^{-3}\right)\end{array}$ & $\begin{array}{l}\text { Measured } \Delta M_{\mathrm{O}} \\
(\text { final })\left(\mu \mathrm{g} \mathrm{m}^{-3}\right)\end{array}$ & $\begin{array}{r}\text { Calculated } \Delta M_{\mathrm{O}} \\
(\text { final })\left(\mu \mathrm{g} \mathrm{m}^{-3}\right)\end{array}$ \\
\hline 90.0 & $27.0 \pm 0.5$ & 26.9 & $9.3 \pm 0.4$ & 8.6 \\
46.1 & $13.5 \pm 0.6$ & 11.5 & $3.8 \pm 0.5$ & 3.4 \\
23.0 & $2.3 \pm 0.5$ & 2.8 & $0.6 \pm 0.3$ & 0.5 \\
12.2 & $0.7 \pm 0.1$ & 0.07 & $0.3 \pm 0.1$ & 0.02 \\
63.6 & $17.8 \pm 0.5$ & 18.0 & $5.0 \pm 0.5$ & 5.6 \\
29.4 & $6.2 \pm 0.8$ & 5.1 & $2.2 \pm 0.5$ & 1.3 \\
47.8 & $11.1 \pm 0.5$ & 9.2 & $3.0 \pm 0.4$ & 3.7 \\
41.6 & $8.4 \pm 0.4$ & $2.4 \pm 0.5$ & 2.9 \\
\hline
\end{tabular}

a Measured values taken from Kroll et al. (2006).

b With $T=298 \mathrm{~K}$.

Table 5. Comparison of measured and modeled* SOA formation $\left(\Delta M_{\mathrm{O}}\right)$ for high- $\mathrm{NO}_{\mathrm{x}}$ conditions.

\begin{tabular}{cccccc}
\hline & $\begin{array}{c}\text { Initial reagent } \\
(\mathrm{ppb})\end{array}$ & $\begin{array}{c}\text { Initial NO } \\
(\mathrm{ppb})\end{array}$ & $\begin{array}{c}\text { Initial NO} \\
(\mathrm{ppb})\end{array}$ & $\begin{array}{c}\text { Measured } \Delta M_{\mathrm{O}} \\
\left(\mu \mathrm{g} \mathrm{m}^{-3}\right)\end{array}$ & $\begin{array}{c}\text { Calculated } \Delta M_{\mathrm{O}} \\
\left(\mu \mathrm{g} \mathrm{m}^{-3}\right)\end{array}$ \\
\hline & 46.7 & 242 & 24 & $6.3 \pm 1.0$ & 6.0 \\
Kroll et al. (2006) & 43.5 & 496 & 30 & $2.9 \pm 1.2$ & 3.3 \\
(isoprene) & 42.7 & 98 & 31 & $6.7 \pm 1.3$ & 5.9 \\
& 49.1 & 51 & 27 & $5.6 \pm 1.3$ & 7.0 \\
& 42.7 & 337 & 68 & $4.6 \pm 1.0$ & 4.7 \\
& 42.0 & 708 & 37 & $1.7 \pm 1.1$ & 1.5 \\
\hline & 500 & 827 & 34 & 74 & 90 \\
Surratt et al. (2006) & 500 & 759 & 112 & 73 & 93 \\
(isoprene) & 500 & 805 & 87 & 104 & 92 \\
& 500 & 825 & 80 & 111 & 91 \\
& 500 & 891 & 74 & 95 & 90 \\
\hline Surratt et al. (2006) & 500 & 791 & 60 & 181 & 136 \\
(methacrolein) & 500 & 898 & 30 & 197 & \\
\hline
\end{tabular}

* With $T=298 \mathrm{~K}$ and $\mathrm{RH}=5 \%$.

where $K_{\text {oligo }}$ represents the ratio of the oligomer mass ( $\left.A_{\text {oligomer }}\right)$ to the monomer mass $\left(A_{\text {monomer }}\right)$. With this simple parameterization, an effective partitioning coefficient can be calculated as follows:

$K_{\text {eff,om }, i}=K_{\text {om }, i}\left(1+K_{\text {oligo }}\right)$

where $K_{\mathrm{om}, i}$ is the absorption equilibrium constant of the monomer. It was calculated by using the saturation vapor pressures obtained with the SIMPOL. 1 method for MGA and its nitrate derivative. The same parameter $K_{\text {oligo }}$ was applied for both BiMGA and BiNGA.

The parameters $\lambda$ and $K_{\text {oligo }}$ were selected to minimize the error between the model and the results from Kroll et al. (2006) and Surratt et al. (2006) by a least-square method. A mean temperature of $298 \mathrm{~K}$ and a relative humidity of $5 \%$ were assumed. Optimization gives $\lambda=0.046$ and $K_{\text {oligo }}=$
64.2. Results are presented in Table 5. Figure 4 shows the results of a simulation for $42.7 \mathrm{ppb}$ of isoprene, $98 \mathrm{ppb}$ of $\mathrm{NO}$ and $31 \mathrm{ppb}$ of $\mathrm{NO}_{2}$. The slight difference between the BiMGA and BiNGA concentrations is due to the slightly different activity coefficients of the two compounds.

The model successfully reproduces the results of Kroll et al. (2006) within the uncertainties of the experiments except for one experiment, (the lowest quantity of $\mathrm{NO}_{\mathrm{x}}$, the model gives a result $\left(7.0 \mu \mathrm{g} \mathrm{m}^{-3}\right)$ close to the upper value, $6.9 \mu \mathrm{g} \mathrm{m}^{-3}$ ). This slight overestimation could be attributed to a calculated quantity of radical $\mathrm{HO}_{2}$ too important or the fact that some reactions (the radical formed from ISHP $+\mathrm{HO}$ could react with NO and forms less SOA) are missing in the gas-phase mechanism. For high isoprene experiments, the model gives relative errors from 5 to $20 \%$, but the model is less sensitive to $\mathrm{NO}_{\mathrm{x}}$ conditions than observed in the 


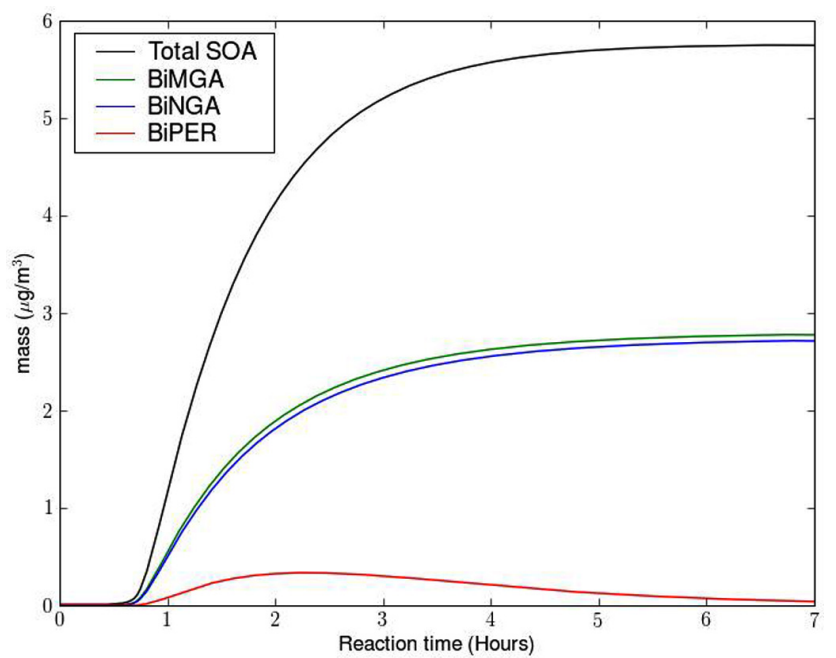

Fig. 4. Evolution of the calculated mass of SOA formed from the photooxidation of isoprene as a function of time for initial concentrations of $42.7 \mathrm{ppb}$ of isoprene, $98 \mathrm{ppb}$ of $\mathrm{NO}$ and $31 \mathrm{ppb}$ of $\mathrm{NO}_{2}$ at $298 \mathrm{~K}$.

experiments. This lack of sensitivity of the model may be due to the fact that the BiMGA/BiNGA ratio in the model does not vary with $\mathrm{NO}_{\mathrm{x}}$ conditions. It may also explain the underestimation of SOA formed when methacrolein is directly oxidized (which leads to a lower BiMGA/BiNGA ratio Surratt et al., 2006).

\section{Influence of parameters}

\subsection{Influence of $\mathrm{NO}_{\mathrm{x}}$ level and $\mathrm{NO}_{2} / \mathrm{NO}$ ratio}

Based on the experiments of Kroll et al. (2006), the SOA yield seems to be maximal for an oxidation of $300 \mathrm{ppb}$ of $\mathrm{NO}_{\mathrm{x}}$ and seems to decrease for higher concentrations. The recent study of Chan et al. (2010) shows that under high$\mathrm{NO}_{\mathrm{x}}$ conditions, the SOA yield strongly depends on the $\left[\mathrm{NO}_{2}\right] /[\mathrm{NO}]$ ratio due to MPAN chemistry (MPAN formation is favored under high $\mathrm{NO}_{2}$ conditions).

To study the impact of the $\mathrm{NO}_{\mathrm{x}}$ level, the amount of SOA formed was calculated as a function of initial $\mathrm{NO}_{\mathrm{x}}$ concentrations (Fig. 5) for different $\left[\mathrm{NO}_{2}\right] /[\mathrm{NO}]$ initial ratios (the ratio may change with time). According to the model results, the amount of SOA decreases strongly only for low $\left[\mathrm{NO}_{2}\right] /[\mathrm{NO}]$ ratio $\left(\mathrm{Fig} .5\right.$ for $\left.\left[\mathrm{NO}_{2}\right] /[\mathrm{NO}]=0.1\right)$ and is below the amount of SOA formed in no- $\mathrm{NO}_{\mathrm{x}}$ conditions $\left(3.5 \mu \mathrm{g} \mathrm{m}^{-3}\right.$ ) for very high concentrations of $\mathrm{NO}_{\mathrm{x}}$ (more than $500 \mathrm{ppb}$ of $\mathrm{NO}_{\mathrm{x}}$ for $45 \mathrm{ppb}$ of oxidized isoprene and an initial $\left[\mathrm{NO}_{2}\right] /[\mathrm{NO}]$ ratio of 0.1$)$. The inhibition of SOA formation for low $\left[\mathrm{NO}_{2}\right] /[\mathrm{NO}]$ ratios is due to the MPAN chemistry. Figure 4 shows that SOA begin to form nearly $1 \mathrm{~h}$ after the

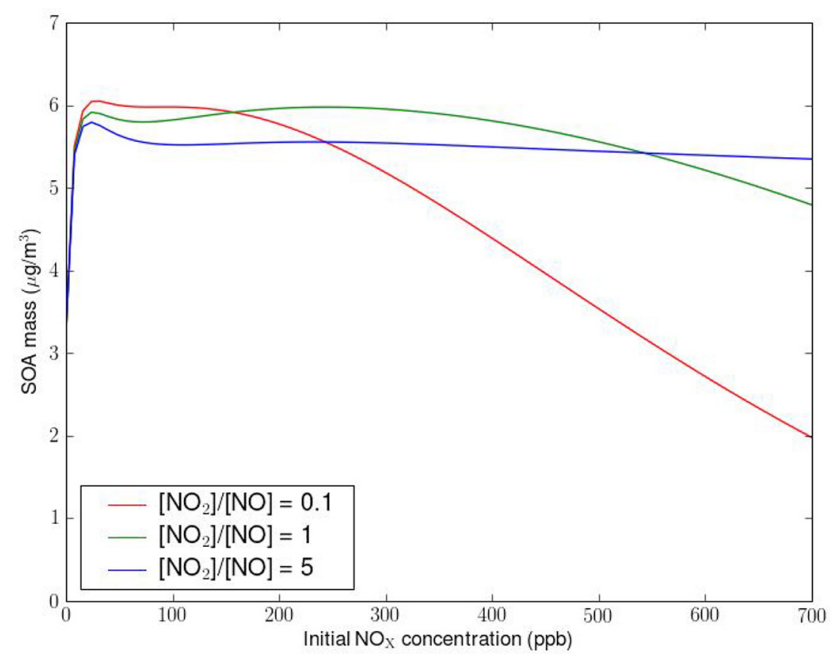

Fig. 5. Evolution of calculated SOA mass with $\mathrm{NO}_{\mathrm{x}}$ for $45 \mathrm{ppb}$ of oxidized isoprene and different initial $\left[\mathrm{NO}_{2}\right] /[\mathrm{NO}]$ ratios.

beginning of oxidation. To observe high concentration of SOA, MPAN formation must be favored after $1 \mathrm{~h}$ and so, a high $\left[\mathrm{NO}_{2}\right] /[\mathrm{NO}]$ ratio after $1 \mathrm{~h}$ must be observed. For an initial $\left[\mathrm{NO}_{2}\right] /[\mathrm{NO}]$ ratio of 0.1 , the ratio after $1 \mathrm{~h}$ is: 53 for $100 \mathrm{ppb}, 52$ for $200 \mathrm{ppb}, 31$ for $300 \mathrm{ppb}$ and 7 for $400 \mathrm{ppb}$. The decrease of SOA for a $\mathrm{NO}_{\mathrm{x}}$ concentration greater than $200 \mathrm{ppb}$ is due to the drop of $\mathrm{NO}_{2}$ during oxidation.

For higher $\left[\mathrm{NO}_{2}\right] /[\mathrm{NO}]$ ratios, it seems that the SOA yield is higher under high- $\mathrm{NO}_{\mathrm{x}}$ conditions than under low- $\mathrm{NO}_{\mathrm{x}}$ conditions. For an initial $\left[\mathrm{NO}_{2}\right] /[\mathrm{NO}]$ ratio of 5 , the quantity of SOA formed appears insensitive to the $\mathrm{NO}_{\mathrm{x}}$ quantity. However, in reality, a stronger sensitivity may be observed if the BiMGA/BiNGA ratio were sensitive to $\mathrm{NO}_{\mathrm{x}}$ concentrations.

For a $\left[\mathrm{NO}_{2}\right] /[\mathrm{NO}]$ ratio of 1 , the final SOA yield (when there is no more SOA growth or loss) was calculated as a function of initial isoprene concentration for several initial concentrations of $\mathrm{NO}_{\mathrm{x}}$ (Fig. 6). For the no- $\mathrm{NO}_{\mathrm{x}}$ simulation, the yield increases and stabilizes at about 3.75\%. In this case, a typical SOA yield curve is obtained. For high- $\mathrm{NO}_{\mathrm{x}}$ simulations, the evolution of the yield is more complex because of the MPAN chemistry. Yields can vary from 5 to $7 \%$ if more than $100 \mathrm{ppb}$ of isoprene is oxidized. For $300 \mathrm{ppb}$ of $\mathrm{NO}_{\mathrm{x}}$, the yield decreases slightly between 300 and $400 \mathrm{ppb}$ of oxidized isoprene and increases for higher concentrations of isoprene.

It is difficult to deduce a general pattern for isoprene SOA formation in presence of $\mathrm{NO}_{\mathrm{x}}$ because of the complex effects of the gas-phase chemistry. Depending on $\mathrm{NO}_{\mathrm{x}}$ concentrations and the $\left[\mathrm{NO}_{2}\right] /[\mathrm{NO}]$ ratio, the yield can be lower or as much as twice higher than the no- $\mathrm{NO}_{\mathrm{x}} \mathrm{SOA}$ yield. However, for atmospheric conditions $\left(\mathrm{NO}_{\mathrm{x}}\right.$ and isoprene concentrations generally inferior to $100 \mathrm{ppb})$, the yield should be 


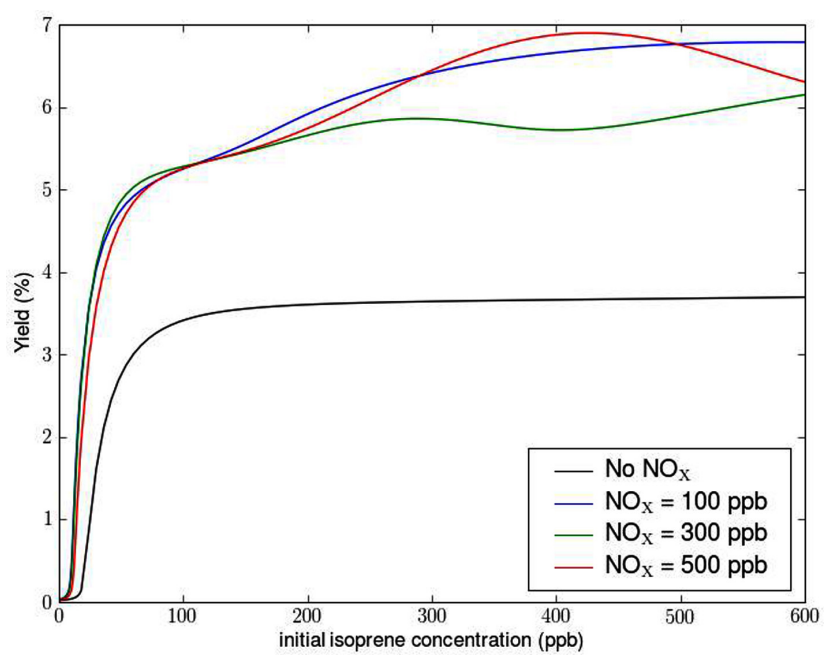

Fig. 6. Evolution of calculated yield with isoprene concentration for different $\mathrm{NO}_{\mathrm{x}}$ concentrations with a $\left[\mathrm{NO}_{2}\right] /[\mathrm{NO}]$ ratio of 1 .

higher under high- $\mathrm{NO}_{\mathrm{x}}$ conditions than under low- $\mathrm{NO}_{\mathrm{x}}$ conditions, when SOA formation occurs in an organic phase.

\subsection{Influence of temperature}

Figure 7 shows the effect of temperature on the amount of SOA formed for different $\left[\mathrm{NO}_{2}\right] /[\mathrm{NO}]$ ratios. In all cases, a decrease of the temperature by $20^{\circ} \mathrm{C}$ leads to an increase of SOA mass by about $2 \mu \mathrm{g} \mathrm{m}^{-3}$. This result can be explained by an increase in SOA volatility when the temperature increases. The temperature affects SOA partitioning more than the kinetics of the reactions leading to the formation of SOA. However, the activation energy was not used for all the reactions due to a lack of data and the chemical kinetics could be in reality more sensitive to temperature.

\subsection{Influence of the BiDER molecular structure}

To investigate the impact of the BiDER molecular structure (which could be very different from the structure of tetrols) on the results of the model optimization, we substitute its structure by that of another compound. We used the peroxy-hemiacetal that could be formed by the particle phase reaction (Kroll and Seinfeld, 2008) of a trihydroxyhydroperoxide with glyoxal. This compound has a molar mass of $224 \mathrm{~g} \mathrm{~mol}^{-1}$ (instead of $136 \mathrm{~g} \mathrm{~mol}^{-1}$ for tetrols). Using this compound, the optimization gives the same yield for BiPER (0.28) but a slightly different saturation vapor pressure $\left(2.2 \times 10^{-6}\right.$ torr instead of $2.6 \times 10^{-6}$ torr $)$. Results obtained for BiPER are not very sensitive then to the choice of the BiDER structure. The results obtained by assuming that BiDER has the structure of tetrols should give a good estimation of BiPER yield and saturation vapor pressure.
For BiDER, the molar yield is lower ( 0.018 instead of 0.030 but the mass yield is the same) and the saturation vapor pressure is lower $\left(2.5 \times 10^{-7}\right.$ torr instead of $4.1 \times 10^{-7}$ torr). Therefore, BiDER volatility may be underestimated in the model.

\section{Extension of the model to humid conditions}

The model described above applies to dry conditions. However, it is important to implement in an air quality model an SOA model that covers the full range of atmospheric conditions including high humidity conditions. Consequently, a parameterization for SOA formation must take into account humid conditions. Moreover, the SOA compounds produced from isoprene photooxidation may be highly hydrophilic due to their structural composition, i.e., short compounds (number of carbons $\leq 5$ ) with several functional groups. Under humid conditions, in presence of both an aqueous phase and an organic liquid phase, isoprene SOA surrogates may partition mostly between the aqueous phase and the gas phase rather than the organic phase and the gas phase.

Several methods have been used to account for the influence of water on SOA formation. On one hand, one can treat the atmospheric particles as internal mixtures (all particles of a same size have the same chemical composition) and solve he thermodynamics with possible phase separation (e.g., mostly organic and aqueous phases) as performed by Pun (2008) and Zuend et al. (2010). On the other hand, one can treat the atmospheric particles as external mixtures with aqueous (mostly inorganic) particles being distinct from hydrophobic (mostly organic) particles as performed by Pun et al. (2002, 2006). The latter approach is used here.

For the extension to humid conditions, a parameterization for the partitioning between the gas phase and the aqueous phase was added to the model described above. It was assumed that all surrogate SOA compounds can partition between the gas phase and any liquid phase (aqueous phase and organic phase). Surratt et al. (2010) showed that under low- $\mathrm{NO}_{\mathrm{x}}$ conditions, an epoxidiol intermediate should be formed from reaction R5 with a high yield (about 75\%). This epoxidiol can lead to methyl-tetrol and other components formation in the presence of an acid aerosol. However, the study of aqueous-phase reactions (Ervens et al., 2008; Volkamer et al., 2009) was considered outside the scope of this work and was not modeled here.

\subsection{Parameterization of the partitioning between an aqueous phase and the gas phase}

To extend the model to humid conditions, the partitioning between the gas phase and the aqueous phase is calculated with a modified Henry's law (Pun et al., 2002):

$H_{i}=\frac{A_{i} \zeta_{i}}{M_{i} \text { LWC } p_{i}}$ 
(a) $\left[\mathrm{NO}_{2}\right] /[\mathrm{NO}]$ ratio of 0.1

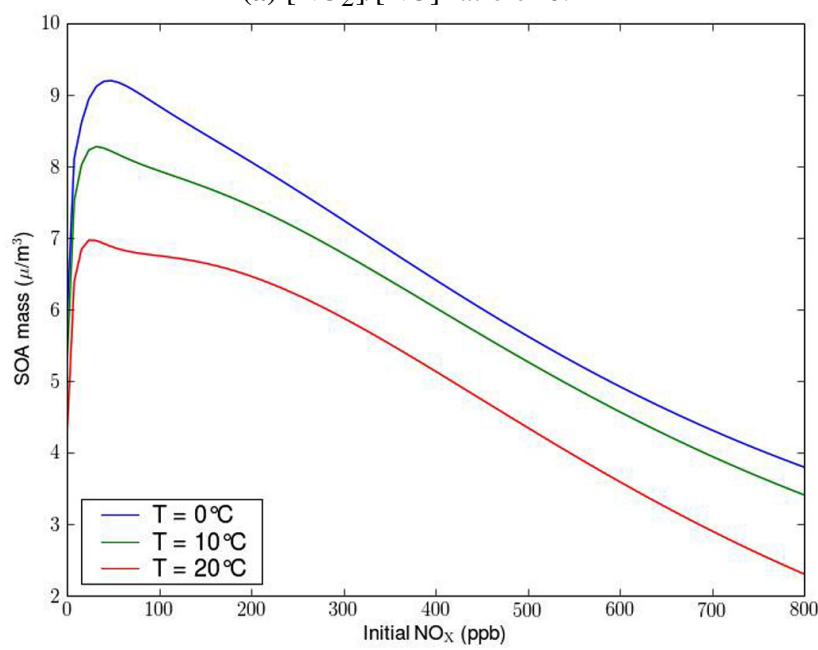

(b) $\left[\mathrm{NO}_{2}\right] /[\mathrm{NO}]$ ratio of 1

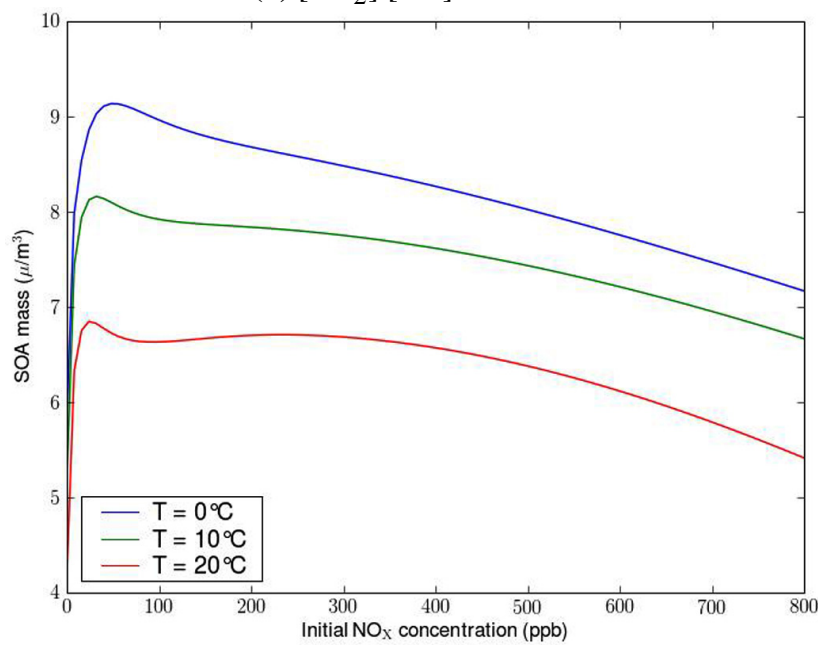

(c) $\left[\mathrm{NO}_{2}\right] /[\mathrm{NO}]$ ratio of 5

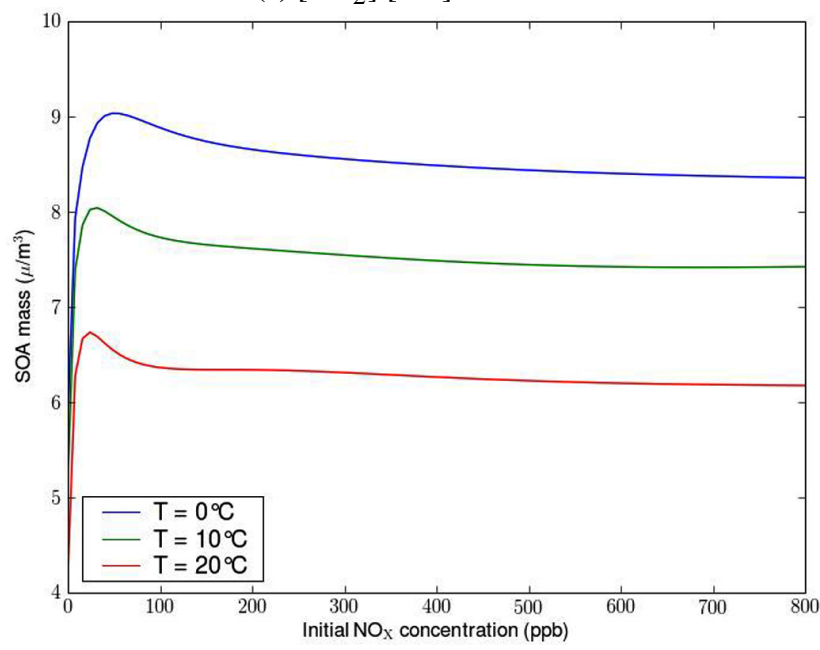

Fig. 7. Evolution of $\mathrm{SOA}$ with $\mathrm{NO}_{\mathrm{x}}$ for $45 \mathrm{ppb}$ of oxidized isoprene at different temperatures for: (a) $\left[\mathrm{NO}_{2}\right] /[\mathrm{NO}]$ ratio of 0.1 , (b) $\left[\mathrm{NO}_{2}\right] /[\mathrm{NO}]$ ratio of $1,(\mathbf{c})\left[\mathrm{NO}_{2}\right] /[\mathrm{NO}]$ ratio of 5 . with $H_{i}$ the Henry's law constant of compound $i\left(\mu \mathrm{M} \mathrm{atm}{ }^{-1}\right)$, $p_{i}$ the partial pressure of compound $i$ in the gas phase (atm), LWC the liquid water content $\left(L_{\text {water }} \mathrm{m}^{-3}\right.$ of air), $M_{i}$ the molar mass of compound $i$ and $\zeta_{i}$ the activity coefficient of compound $i$ in the aqueous phase defined by reference to the infinite dilution. $\zeta_{i}$ can be computed by using the UNIFAC model:

$\zeta_{i}=\frac{\gamma_{i}}{\gamma_{i}^{\infty}}$

where $\gamma_{i}$ is the activity coefficient of the compound $i$ in the aqueous phase computed with UNIFAC and $\gamma_{i}^{\infty}$ is the activity coefficient of compound $i$ at infinite dilution computed with UNIFAC.

Different methods can be used to determine the Henry's law constant. Functional group methods give very high values for the Henry's law constant of BiMT $\left(2.7 \times 10^{16} \mathrm{Matm}^{-1}\right.$ and $1.66 \times 10^{16} \mathrm{Matm}^{-1}$ with the methods of Meylan and Howard (2000) and Suzuki et al. (1992) respectively). On the contrary, the HENRYWIN bond contribution method of Meylan and Howard (2000, 1991) predicts a lower value for BiMT: $2.45 \times 10^{6} \mathrm{M} \mathrm{atm}^{-1}$. However, according to the data available in RaventosDuran et al. (2010), the HENRYWIN bond contribution method seems to underestimate the Henry's law constant for compounds with several hydroxy groups (for example, for propane-1,3-diol, this method predicts a Henry's law constant of $6.31 \times 10^{3} \mathrm{M} \mathrm{atm}^{-1}$ whereas the experimental value is $1.0 \times 10^{6} \mathrm{M} \mathrm{atm}^{-1}$ ). SPARC online (Hilal et al., 2008) seems then to provide the best estimation for Henry's constants $\left(3.38 \times 10^{10} \mathrm{M} \mathrm{atm}^{-1}\right.$ for BiMT and $5.25 \times 10^{8} \mathrm{M} \mathrm{atm}^{-1}$ for BiMGA). However, SPARC online does not provide algorithms to calculate the Henry's law constants of the other compounds.

We chose to calculate the other Henry's law constants by reference to either BiMT or BiMGA using the following equation:

$H_{i}=\frac{\gamma_{j}^{\infty} P_{j}^{\mathrm{o}}}{\gamma_{i}^{\infty} P_{i}^{\mathrm{o}}} H_{j}$

where $j$ is the compound of reference (BiMT or BiMGA) and $i$ is the compound for which the Henry's law constant is wanted. The Henry's law constants for BiPER, BiDER and $\mathrm{C}_{5} \mathrm{H}_{9} \mathrm{~N}_{3} \mathrm{O}_{10}$ were calculated by reference to BiMT. The Henry's law constant for BiNGA was calculated by reference to BiMGA. The saturation vapor pressures used in the model for dry conditions were used for the calculation. The calculated values at $298 \mathrm{~K}$ are presented in Table 6 .

\subsection{Influence of an aqueous phase on SOA formation}

The partitioning of the surrogate compounds under atmospheric conditions was calculated for four different cases. In the first case, SOA partition between the gas phase and 
Table 6. Calculated Henry's law constants for SOA surrogate species.

\begin{tabular}{ll}
\hline Surrogate species & $H_{i}$ at $298 \mathrm{~K}\left(\mathrm{M} \mathrm{atm}^{-1}\right)$ \\
\hline BiMT & $3.30 \times 10^{10}$ \\
$\mathrm{C}_{5} \mathrm{H}_{9} \mathrm{~N}_{3} \mathrm{O}_{10}$ & $4.75 \times 10^{6}$ \\
BiMGA & $5.25 \times 10^{8}$ \\
BiNGA & $3.73 \times 10^{7}$ \\
BiPER & $8.09 \times 10^{9}$ \\
BiDER & $8.91 \times 10^{10}$ \\
\hline
\end{tabular}

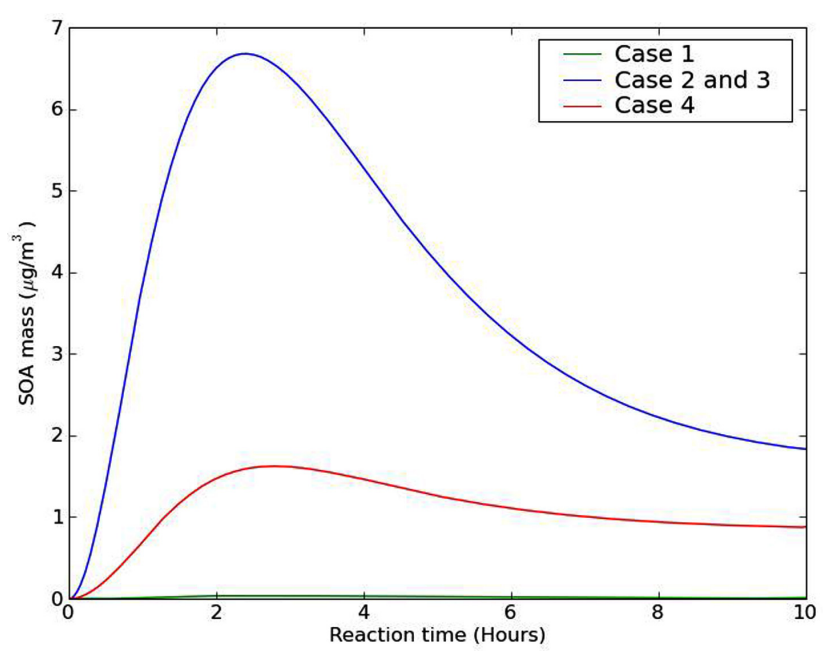

Fig. 8. Effect of an aqueous phase on SOA formation under no- $\mathrm{NO}_{\mathrm{x}}$ conditions for $10 \mathrm{ppb}$ of initial isoprene concentration for different cases. Case 1: Condensation on $5 \mu \mathrm{g} \mathrm{m}^{-3}$ of POA. Case 2: Condensation on $50 \mu \mathrm{g} \mathrm{m}^{-3}$ of liquid water. Case 3: Condensation on $5 \mu \mathrm{g} \mathrm{m}^{-3}$ of POA and on $50 \mu \mathrm{g} \mathrm{m}^{-3}$ of liquid water. Case 4: Condensation on $5 \mu \mathrm{g} \mathrm{m}^{-3}$ of an ideal organic phase.

an organic phase constituted by primary organic aerosols (POA). A mean value of $5 \mu \mathrm{g} \mathrm{m}^{-3}$ for POA concentrations was chosen as follows: $40 \%$ of $\mathrm{C} 23 \mathrm{H} 47 \mathrm{COOH}$, $5 \%$ of $\mathrm{C} 8 \mathrm{H} 17 \mathrm{CH}=\mathrm{CHC} 7 \mathrm{H} 14 \mathrm{COOH}, 15 \%$ of 4 -(2-propio)syringone, $12 \%$ of $\mathrm{C} 29 \mathrm{H} 60$ and $28 \%$ of 2-carboxybenzoic acidic (EPRI, 1999). In the second case, SOA partition between the gas phase and an aqueous phase. A value of $50 \mu \mathrm{g} \mathrm{m}^{-3}$ of liquid water was used in the second case. The aqueous aerosol was supposed to be too acid for BiMGA and BiNGA to dissociate. In the third case, SOA can condense on $5 \mu \mathrm{g} \mathrm{m}^{-3}$ of POA and on $50 \mu \mathrm{g} \mathrm{m}^{-3}$ of liquid water. In the fourth case, surrogates can condense on an organic phase assumed to be ideal (activity coefficients equal to 1).

Under no- $\mathrm{NO}_{\mathrm{x}}$ conditions $\left([\mathrm{NO}]=\left[\mathrm{NO}_{2}\right]=0.0\right)$, no substantial amount of SOA is formed in the first case (maximum of SOA formed is $0.027 \mu \mathrm{g} \mathrm{m}^{-3}$ ) whereas a significant amount is formed in the second case. The low amount of SOA formed in the first case is due to low affinity of the surrogate compounds formed under those conditions (mainly BiPER and BiDER) with POA. In the second and third case, the same amount of SOA is formed (because all SOA compounds seem to partition only in the aqueous phase). Figure 8 shows the evolution of SOA formed for the second and third cases. A substantial amount of isoprene is formed $\left(1.6 \mu \mathrm{g} \mathrm{m}^{-3}\right.$ at the end of the oxidation and a maximum at $6.7 \mu \mathrm{g} \mathrm{m}^{-3}$ ). The amount of SOA formed is even greater than in the case where SOA would condense on an ideal organic phase, which gives much greater concentrations than the nonideal organic phase case. This result shows the importance of taking into account the non-ideality of particles for SOA partitioning. Furthermore, SOA formed from isoprene photooxidation under low- $\mathrm{NO}_{\mathrm{x}}$ conditions are not likely to condense on POA (due to non-ideality of the organic phase), it would more likely condense efficiently on an aqueous phase. It should be noted that, whereas surrogates do not condense on POA, they condense almost entirely on the aqueous phase (only $1 \%$ of BiPER remains in the gas phase).

Under high- $\mathrm{NO}_{\mathrm{x}}$ conditions $\left([\mathrm{NO}]=\left[\mathrm{NO}_{2}\right]=50 \mathrm{ppb}\right)$, all the components formed are not highly hydrophilic. Figure 9 shows the quantity of SOA formed for the different cases under high- $\mathrm{NO}_{\mathrm{x}}$ conditions. There is still a lower quantity of SOA $\left(0.16 \mu \mathrm{g} \mathrm{m}^{-3}\right)$ formed when SOA condense on POA than when they condense on an aqueous phase $\left(0.59 \mu \mathrm{g} \mathrm{m}^{-3}\right)$. But, contrary to the low- $\mathrm{NO}_{\mathrm{x}}$ conditions, the third case shows that a non-negligible part of the surrogates condense on the organic phase. The fourth case (ideal organic phase) strongly increases the mass of SOA. The difference between low- $\mathrm{NO}_{\mathrm{x}}$ and high- $\mathrm{NO}_{\mathrm{x}}$ conditions is due to lower Henry's law constants of the surrogate species, which dominate under high$\mathrm{NO}_{\mathrm{x}}$ conditions. Whereas, the measured SOA yield was higher for dry conditions under high- $\mathrm{NO}_{\mathrm{x}}$ conditions (but for concentrations of $\mathrm{NO}_{\mathrm{x}}$ less than $300 \mathrm{ppb}$ ) than under low$\mathrm{NO}_{\mathrm{x}}$ conditions, it is possible that in the atmosphere under high- $\mathrm{NO}_{\mathrm{x}}$ conditions, less SOA could be formed due to lower water solubility of the corresponding SOA. The increase in SOA mass under humid conditions is commensurate with the results obtained by Pun (2008) who estimates, using a different approach, an increase by a factor of five of SOA mass by taking into account the hydrophilic properties of SOA from isoprene.

To explain the absorption of surrogates in the organic phase in high- $\mathrm{NO}_{\mathrm{x}}$ but not in low- $\mathrm{NO}_{\mathrm{x}}$, the distribution of the $\mathrm{SOA}$ (formed from the oxidation of $10 \mathrm{ppb}$ of isoprene with $50 \mathrm{ppb}$ of $\mathrm{NO}$ and $\mathrm{NO}_{2}$ ) between the organic and aqueous phases for different $M_{\text {water }} / M_{\text {organic }}$ ratios is shown in Fig. 10. BiMT, BiPER and BiDER (compounds formed under low$\mathrm{NO}_{\mathrm{x}}$ conditions) are only present in the aqueous phase and do not condense significantly in the organic phase. BiMGA (formed under high- $\mathrm{NO}_{\mathrm{x}}$ ) does not condense on the aqueous as efficiently as the surrogates formed under low- $\mathrm{NO}_{\mathrm{x}}$ conditions. However, for an $M_{\text {water }} / M_{\text {organic }}$ ratio of $1.60 \%$ of particulate BiMGA is in the aqueous phase and around $95 \%$ 


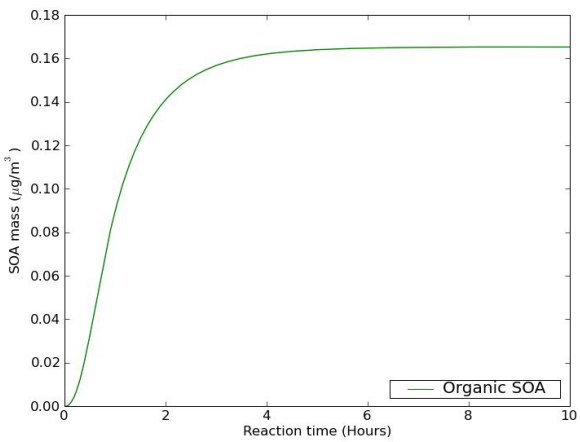

Case 1: $5 \mu \mathrm{g} \cdot \mathrm{m}^{-3}$ of POA

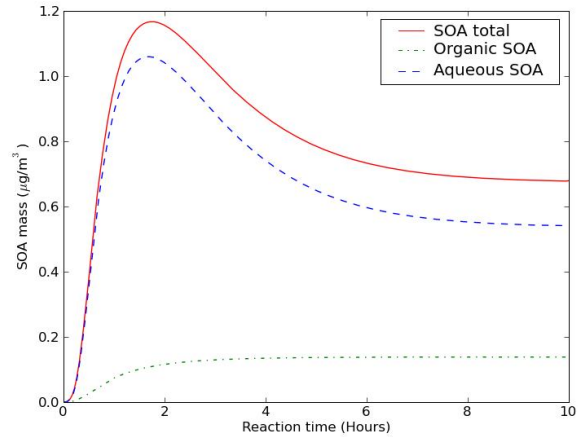

Case 3: $5 \mu \mathrm{g} \cdot \mathrm{m}^{-3}$ of POA and $50 \mu \mathrm{g} \cdot \mathrm{m}^{-3}$ of water

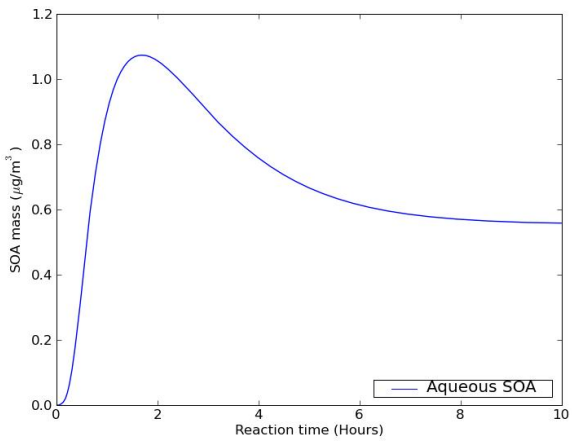

Case 2: $50 \mu \mathrm{g} \cdot \mathrm{m}^{-3}$ of water

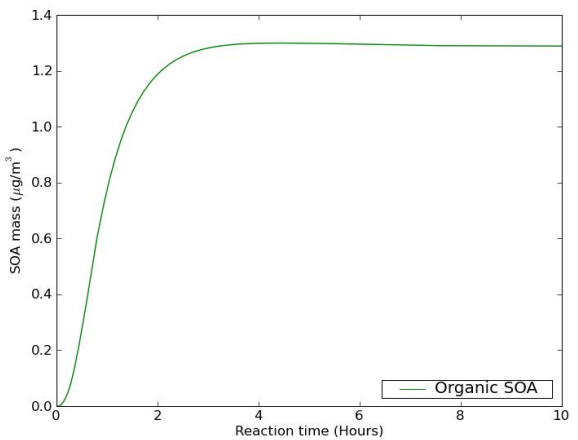

Case 4: $5 \mu \mathrm{g} \cdot \mathrm{m}^{-3}$ of POA Ideal Organic Phase

Fig. 9. Effect of an aqueous phase on $\mathrm{SOA}$ formation under high- $\mathrm{NO}_{\mathrm{x}}$ conditions $\left([\mathrm{ISO}]=10 \mathrm{ppb},[\mathrm{NO}]=\left[\mathrm{NO}_{2}\right]=50 \mathrm{ppb}\right)$. Case $1: \mathrm{Con}-$ densation on $5 \mu \mathrm{g} \mathrm{m}^{-3}$ of POA. Case 2: Condensation on $50 \mu \mathrm{g} \mathrm{m}^{-3}$ of liquid water. Case 3: Condensation on $5 \mu \mathrm{g} \mathrm{m} \mathrm{m}^{-3}$ of POA and on $50 \mu \mathrm{g} \mathrm{m}^{-3}$ of liquid water. Case 4 : Condensation on $5 \mu \mathrm{g} \mathrm{m}^{-3}$ of an ideal organic phase.

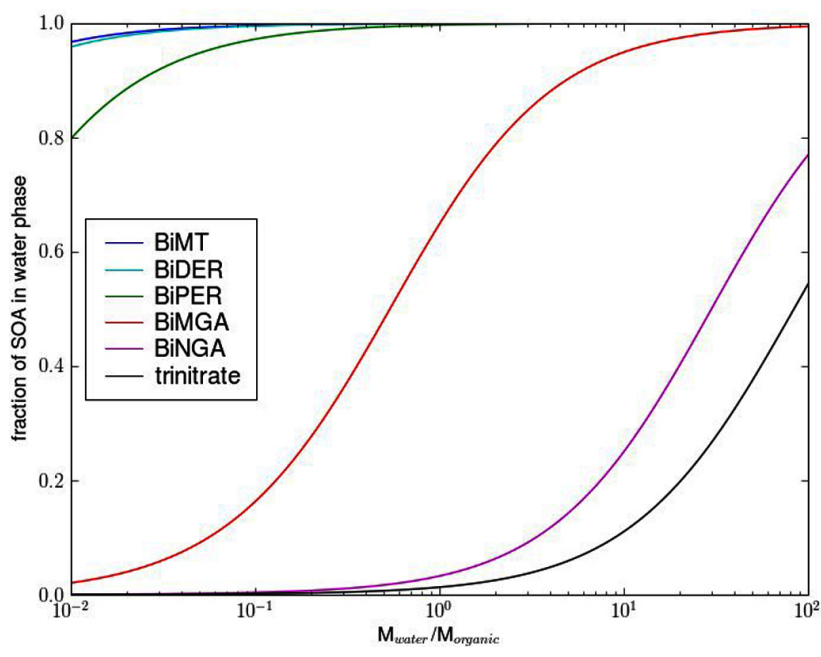

Fig. 10. Distribution of the absorbed surrogates between the aqueous phase and the organic phase for different $M_{\text {water }} / M_{\text {organic }}$ ratios if oligomerization only happens in the organic phase. for a ratio of 10 . When, the $M_{\text {water }} / M_{\text {organic }}$ ratio is superior to 1 in the atmosphere, BiMGA should partition preferably between the aqueous phase and the gas phase. BiNGA and $\mathrm{C}_{5}$-hydroxy-trinitrate seem to be hydrophobic because even for an $M_{\text {water }} / M_{\text {organic }}$ ratio of 10 , they condense preferably on the organic phase. The condensation of SOA on the organic phase under high- $\mathrm{NO}_{\mathrm{x}}$ conditions is then due to the hydrophobic properties of BiNGA (only a small quantity of $\mathrm{C}_{5}$-hydroxy-trinitrate is formed under the conditions considered here).

The AER/EPRI/Caltech model (AEC) (Pun et al., 2002, $2003,2006)$ is a model for SOA formation that takes into account the hydrophilic and hydrophobic properties of surrogates. It distinguishes compounds into two types: hydrophilic compounds (which are absorbed only in an aqueous particle) and hydrophobic compounds (which are absorbed only in an organic particle). In AEC, a compound cannot condense on both phases simultaneously; we investigate here the uncertainty associated with this formulation. According to the distribution of the surrogates, BiMT, BiPER, BiDER and BiMGA may be considered hydrophilic compounds and BiNGA and $\mathrm{C}_{5} \mathrm{H}_{9} \mathrm{~N}_{3} \mathrm{O}_{10}$ hydrophobic compounds. Under 


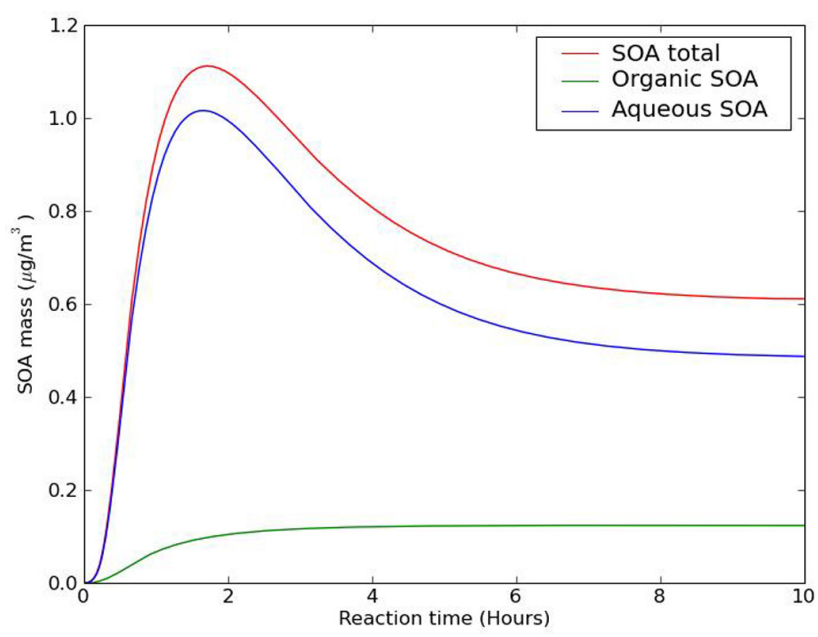

Fig. 11. Simulated SOA concentration in aqueous and organic phases for $10 \mathrm{ppb}$ of isoprene and high- $\mathrm{NO}_{\mathrm{x}}$ conditions $\left([\mathrm{NO}]=\left[\mathrm{NO}_{2}\right]=50 \mathrm{ppb}\right)$ assuming all the surrogates are hydrophilic except for BiNGA and $\mathrm{C}_{5} \mathrm{H}_{9} \mathrm{~N}_{3} \mathrm{O}_{10}$.

low- $\mathrm{NO}_{\mathrm{x}}$ conditions, as the compounds formed are highly hydrophilic and condense almost entirely on aqueous particles, the hypothesis of AEC does not change the results significantly. Figure 11 shows the evolution of SOA formed with time for the high- $\mathrm{NO}_{\mathrm{x}}$ case, assuming that surrogates are only hydrophilic or only hydrophobic. The difference between the case where all compounds can partition among all the phases (see Fig. 9) and the case with the hypothesis of AEC is greater for high- $\mathrm{NO}_{\mathrm{x}}$ conditions because $\mathrm{BiMGA}$ and BiNGA (major components formed under high- $\mathrm{NO}_{\mathrm{x}}$ conditions) are neither totally hydrophilic nor hydrophobic. In this case, the mass of SOA is underestimated by the AEC hypothesis by $11 \%$ : $0.61 \mathrm{~g} \mathrm{~m}^{-3}$ (Fig. 11) with the AEC hypothesis against $0.68 \mu \mathrm{g} \mathrm{m}^{-3}$ (Fig. 9) without the AEC hypothesis.

\subsection{Influence of oligomerization and particle $\mathrm{pH}$ on partitioning}

SOA surrogates have been separated between hydrophobic and hydrophilic compounds, however, calculated partitioning can change whether oligomerization is taken into account in the computation or not. We assumed that esterification does not occur in the aqueous phase, although Altieri et al. (2008) observed formation of oligoesters in an aqueous phase. Additional absorption of acidic SOA species (BiMGA and BiNGA) occurs by dissociation in an aqueous phase. For a $\mathrm{pH}$ superior to $\mathrm{pKa}(\mathrm{pKa}=4$ estimated for BiMGA with SPARC online), BiMGA and BiNGA would, therefore, dissociate and would be more efficiently absorbed. On the other hand, oligomerization in the organic phase could be less important in the atmosphere due to less concentrated monomers. The amount of SOA formed (for $10 \mathrm{ppb}$ of iso- prene, $50 \mathrm{ppb}$ of $\mathrm{NO}, 50 \mathrm{ppb}$ of $\mathrm{NO}_{2}, 5 \mu \mathrm{g} \mathrm{m}^{-3}$ of POA and $50 \mu \mathrm{g} \mathrm{m}^{-3}$ of liquid water) was simulated to investigate the sensitivity of the system to additional absorption due to acid dissociation and oligomerization.

To investigate the effect of potential oligomerization in the aqueous phase and $\mathrm{pH}$, an effective Henry's law constant for BiMGA and BiNGA was used:

$H_{\text {eff }, i}=H_{i}\left(1+K_{\text {oligo }}\right)$

where $K_{\text {oligo }}$ is the same constant as the one in Eq. 3 (it supposes that additional absorption due to dissociation and oligomerization occurs with the same extent in both phases). Figure 12a shows the evolution of the SOA mass. Additional absorption of BiMGA and BiNGA greatly increases the amount of SOA formed $\left(1.7 \mu \mathrm{g} \mathrm{m}^{-3}\right.$ against $0.68 \mu \mathrm{g} \mathrm{m}^{-3}$ without additional absorption). Moreover, there is almost no condensation on POA: all the condensation occurs on the aqueous phase. Figure 13a shows the distribution of the surrogates between the two condensed phases for different $M_{\text {water }} / M_{\text {organic }}$ ratios. For an $M_{\text {water }} / M_{\text {organic }}$ ratio of 1 , almost all the particulate BiMGA is in the aqueous phase and nearly $80 \%$ of the particulate BiNGA is in the aqueous phase. Contrary to the case where there is no additional absorption in the aqueous phase (see Fig. 10), BiNGA can then be considered hydrophilic when its additional absorption is accounted for.

To investigate the possible absence of oligomerization in the organic phase, $K_{\text {oligo }}=0$ was used. Figure $12 \mathrm{~b}$ shows the evolution of the SOA mass without oligomerization in the organic phase. The final SOA mass is reduced by $16 \%$ $\left(0.57 \mu \mathrm{g} \mathrm{m}^{-3}\right.$ without oligomerization against $0.68 \mu \mathrm{g} \mathrm{m}^{-3}$ with oligomerization). There is no significant absorption of the surrogates on the organic phase. Figure 13b shows the distribution of the surrogates between the two phases. As in the previous case, BiNGA partitions more efficiently between the aqueous phase and the gas phase and can be considered hydrophilic when its oligomerization in the organic phase is not accounted for.

Whether BiNGA condenses on POA or an aqueous phase depends on potential additional absorption in the aqueous phase by potential oligomerization and dissociation and on the extent of oligomerization in the organic phase. Most of the components can be classified as hydrophilic (BiMT, BiPER, BiDER and BiMGA) but BiNGA can be considered either as hydrophobic or hydrophilic, depending on oligomerization in the organic phase or additional absorption in the aqueous phase.

\subsection{Sensitivity of the model to Henry's law constants}

One of the main uncertainties of the model is the values of Henry's law constants. The constants used here were estimated using the saturation vapor pressure and the activity coefficient at infinite dilution; however, as discussed above, 
(a) additional absorption in the aqueous phase (acid dissociation and oligomerization)

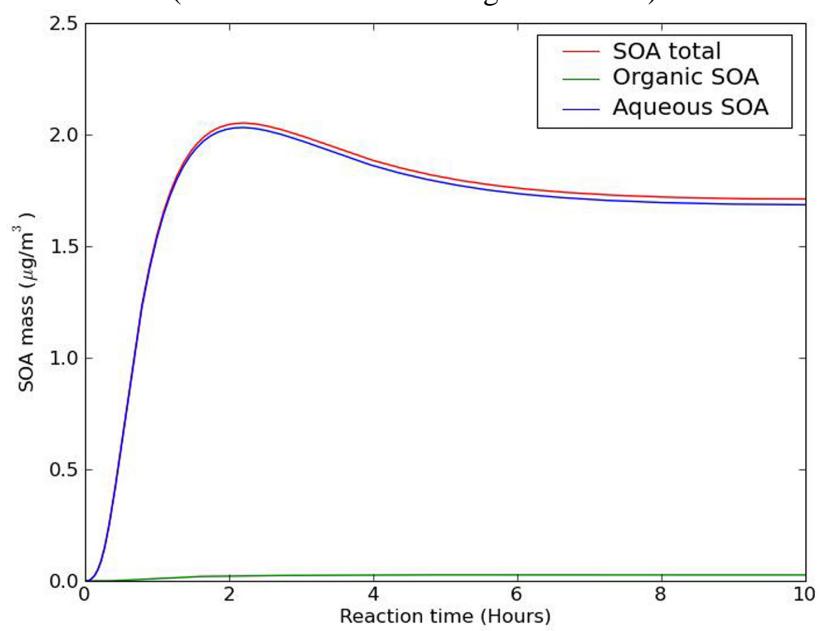

(b) no additional absorption in the aqueous phase and no oligomerization in the organic phase

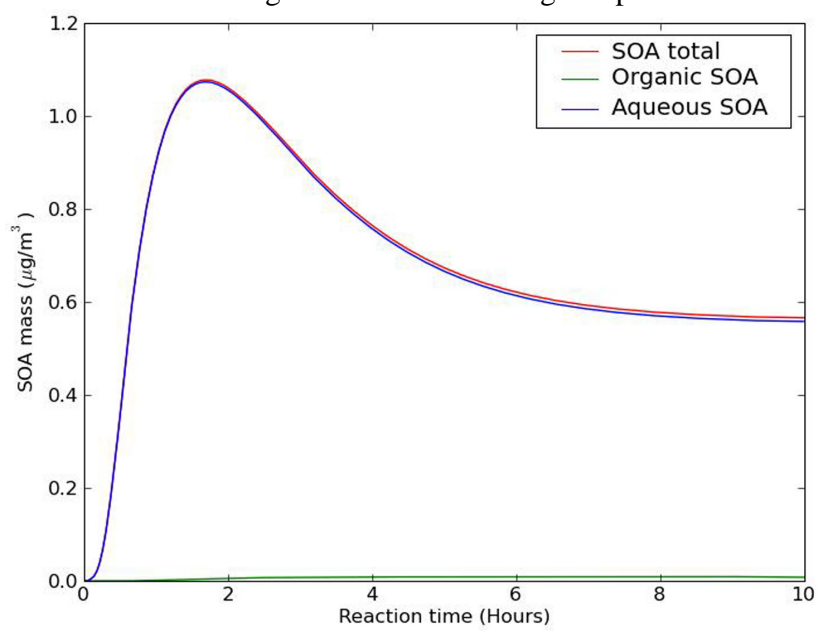

Fig. 12. Evolution with time of the mass of SOA formed: (a) with additional absorption in the aqueous phase (acid dissociation and oligomerization) and (b) with no additional absorption in the aqueous phase and no oligomerization in the organic phase.

other methods may lead to quite different results. For that reason, a sensitivity study was conducted to evaluate the impact of those uncertainties on liquid-gas partitioning.

Under low- $\mathrm{NO}_{\mathrm{x}}$ conditions, the partitioning is not very sensitive to the values. If Henry's law constants are divided by $2,1.76 \mathrm{\mu g} \mathrm{m}^{-3}$ of SOA are formed instead of $1.83 \mu \mathrm{g} \mathrm{m}^{-3}$ (for $50 \mu \mathrm{g} \mathrm{m}^{-3}$ of liquid water and $10 \mathrm{ppb}$ of initial isoprene). If the Henry's law constants are divided by $10,0.92 \mu \mathrm{g} \mathrm{m}^{-3}$ is formed (i.e. half of SOA previously formed). On the contrary, when Henry's law constants are multiplied by 10 , the quantity of SOA does not change significantly $\left(1.86 \mu \mathrm{g} \mathrm{m}^{-3}\right.$ instead of $\left.1.83 \mu \mathrm{g} \mathrm{m}^{-3}\right)$ because most of the SOA species are already present in the condensed phase. So, for BiMT, BiPER and BiDER, the amount of (a) additional absorption in the aqueous phase (acid dissociation and oligomerization)

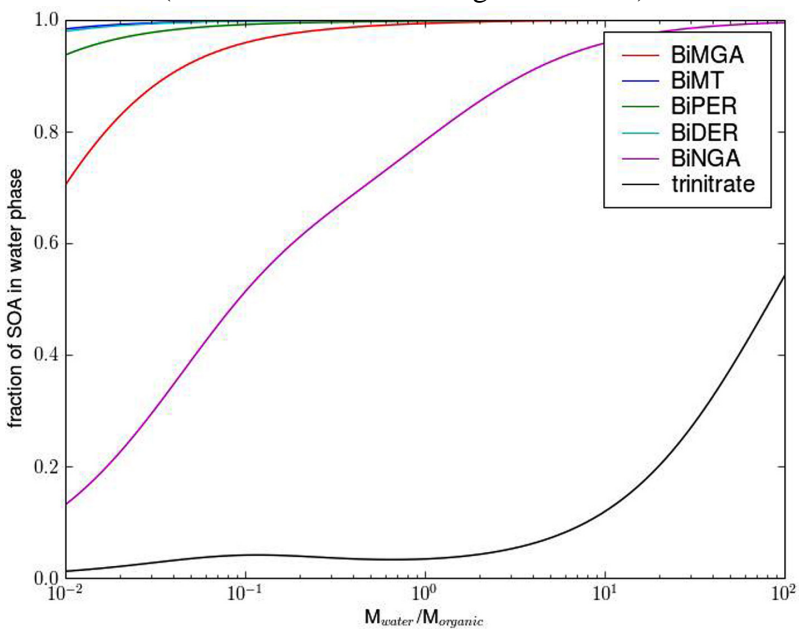

(b) no additional absorption in the aqueous phase and no oligomerization in the organic phase

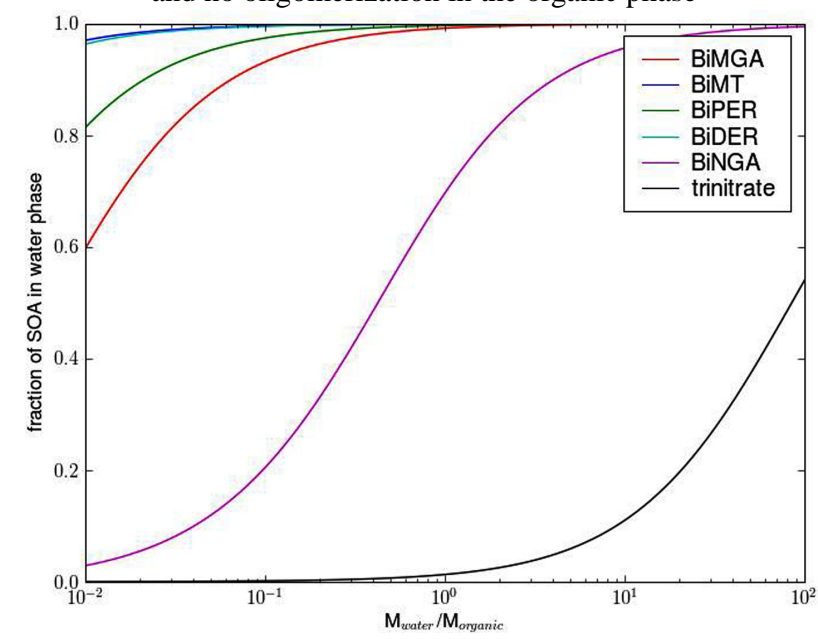

Fig. 13. Distribution of the absorbed surrogates between the aqueous phase and the organic phase for different $M_{\text {water }} / M_{\text {organic }}$ ratios: (a) with additional absorption in the aqueous phase (acid dissociation and oligomerization) and (b) with no additional absorption in the aqueous phase and no oligomerization in the organic phase.

SOA formed does not change significantly for a small decrease of the Henry's law constants or for an important increase of the Henry's law constant. Of course, the impact of Henry's law constant values is more important for lower quantity of liquid water, but even at $5 \mu \mathrm{g} \mathrm{m}^{-3}$ of liquid water, Henry's law constant values have a small impact on SOA formation: $1.46 \mu \mathrm{g} \mathrm{m}^{-3}$ of SOA for Henry's law constants divided by two, and $1.86 \mu \mathrm{g} \mathrm{m}^{-3}$ for Henry's law constants multiplied by ten instead of $1.73 \mu \mathrm{g} \mathrm{m}^{-3}$. If the structure of the peroxy-hemiacetal that could be formed by the particle phase reaction (Kroll and Seinfeld, 2008) of a trihydroxyhydroperoxide with glyoxal, the Henry's law constant of BiDER should be higher (less volatile and more affinity with 
water) by about a factor 4 . But, as the formation of SOA is not very sensitive to Henry's law constants, the impact of the uncertainty of the BiDER structure should be limited.

Under high- $\mathrm{NO}_{\mathrm{x}}$ conditions, the partitioning is more sensitive. However, it was shown previously that using effective Henry's law constants taking into account additional absorption due to oligomerization and dissociation greatly influences the partitioning of the surrogates. The main uncertainty for BiMGA and BiNGA partitioning is then the extent of the additional absorption rather than the actual Henry's law constants for BiMGA and BiNGA.

For $\mathrm{C}_{5} \mathrm{H}_{9} \mathrm{~N}_{3} \mathrm{O}_{10}$ formed by oxidation of isoprene by $\mathrm{NO}_{3}$ radicals, as the component seems hydrophobic, the value of its Henry's law constant does not impact its partitioning noticeably.

\section{Conclusions}

A model for SOA formation from isoprene oxidation that takes into account different chemical regimes and the hydrophilic properties of SOA has been developed. For low$\mathrm{NO}_{\mathrm{x}}$ conditions, SOA was found to be highly hydrophilic and it is likely that components formed would condense on an aqueous phase rather than on an organic phase. For high$\mathrm{NO}_{\mathrm{x}}$ conditions, methyl glyceric acid (BiMGA) was found to be hydrophilic whereas the nitrate derivative (BiNGA) can be considered as hydrophilic or hydrophobic depending on the hypothesis formulated.

A major conclusion is the importance of the hydrophilic properties of SOA formed from isoprene oxidation. Because the parameterizations derived from smog chambers experiments apply to dry conditions, SOA formation could be underestimated in current models.

This SOA model can be implemented in an air quality model to evaluate the amount of isoprene-SOA formed in the atmosphere. However, several questions remain before implementing this model. Are all the pathways described here important for SOA formation? The formation of $\mathrm{C}_{5}$ hydroxy-trinitrate may not be relevant in the atmosphere and in any case, it could be a minor pathway for the formation of SOA in the atmosphere. If 3-D simulations show that those compounds do not contribute significantly to the SOA burden, this pathway could be removed from the model. Can the number of surrogates be reduced? Some surrogates like BiMT and BiDER have similar thermodynamic properties (same molecular structure and high Henry's law constants), and they could perhaps be merged into a single surrogate.

To develop this model, several assumptions hwere made. Readers should be aware of these assumptions and that several uncertainties remain. Which molecular structure for BiDER should be chosen? Can the products formed in experimental chambers be formed under all conditions in the atmosphere? For example, if BiDER is formed by reaction in an organic phase, it is possible that it is not formed when the compounds tend to condense on liquid water. To what extent does the oligomerization occur in the atmosphere for BiMGA and BiNGA. Are the estimated Henry's law constants and saturation vapor pressures reliable enough for extrapolation to atmospheric conditions? For example, Barley and McFiggans (2010) showed that results of models of SOA formation are very sensitive to saturation vapor pressures.

It should be noted that the main uncertainties of the model concern the high- $\mathrm{NO}_{\mathrm{x}}$ regime. However, isoprene is emitted by biogenic sources in remote areas where concentrations of $\mathrm{NO}_{\mathrm{x}}$ are low. Most of SOA should, therefore, be formed under low- $\mathrm{NO}_{\mathrm{x}}$ conditions and the impact of the uncertainties of the high- $\mathrm{NO}_{\mathrm{x}}$ regime should be limited.

Acknowledgements. This work was funded in part by ADEME, the French Agency for the Environment and Energy Management. Thanks are due to Nathalie Poisson, ADEME, JeanFrançois Doussin, LISA, Université Paris-Est, and Anne Monod, Laboratoire Chimie Provence, Université Aix-Marseille for useful discussions.

Edited by: H. Saathoff

\section{References}

Altieri, K., Seitzinger, S., Carlton, A., Turpin, B., Klein, G., and Marshall, A.: Oligomers formed through in-cloud methylglyoxal reactions: chemical composition, properties, and mechanisms investigated by ultra-high resolution FT-ICR Mass Spectrometry, Atmos. Environ., 42, 1476-1490, doi:10.1016/j.atmosenv.2007. 11.015, 2008.

Barley, M. H. and McFiggans, G.: The critical assessment of vapour pressure estimation methods for use in modelling the formation of atmospheric organic aerosol, Atmos. Chem. Phys., 10, 749767, doi:10.5194/acp-10-749-2010, 2010.

Carlton, A. G., Wiedinmyer, C., and Kroll, J. H.: A review of Secondary Organic Aerosol (SOA) formation from isoprene, Atmos. Chem. Phys., 9, 4987-5005, doi:10.5194/acp-9-4987-2009, 2009.

Carter, W., Cocker III, D., Fitz, D., Malkina, I., Bumiller, K., Sauer, C., Pisano, J., Bufalino, C., and Song, C.: A new environmental chamber for evaluation of gas-phase chemical mechanisms and secondary aerosol formation, Atmos. Environ., 39, 7768-7788, doi:10.1016/j.atmosenv.2005.08.040, 2005.

Chan, A., Chan, M., Surratt, J., Chhabra, P., Loza, C., Crounsoe, J., Yee, L., Flagan, R., Wennberg, P., and Seinfeld, J.: Role of aldehyde chemistry and NOx concentrations in secondary organic aerosol formation, Atmos. Chem. Phys. Discuss., 10, 1021910269, doi:10.5194/acpd-10-10219-2010, 2010.

Claeys, M., Graham, B., Vas, G., Wang, W., Vermeylen, R., Pashynska, V., Cafmeyer, J., Guyon, P., Andreae, M., Araxo, P., and Maenhaut, W.: Formation of secondary organic aerosols through photooxidation of isoprene, Science, 303, 1173-1176, doi:10.1126/science.1092805, 2004.

Cocker III, D., Flagan, R., and Seinfeld, J.: State-of-the-art chamber facility for studying atmospheric aerosol chemistry, Environ. Sci. Technol., 35, 2594-2601, doi:10.1021/es0019169, 2001. 
Comernolle, S., Ceulemans, K., and Müller, J.-F.: Influence of non-ideality on condensation to aerosol, Atmos. Chem. Phys., 9, 1325-1338, doi:10.5194/acp-9-1325-2009, 2009.

Edney, E., Kleindienst, T., Jaoui, M., Lewabdowski, M., Offenberg, J., Wang, W., and Claeys, M.: Formation of 2-methyltetrols and 2-methylglyceric acid in secondary organic aerosol from laboratory irradiated isoprene/ $\mathrm{NO}_{\mathrm{X}} / \mathrm{SO}_{2} /$ air mixtures and their detection in ambient PM2.5 samples collected in the eastern United States, Atmos. Environ., 39, 5281-5289, doi:10.1016/j. atmosenv.2005.05.031, 2005.

EPRI: Organic Aerosol Partition Module Documentation, Tech. rep., 1999

Ervens, B., Carlton, A., Turpin, B., Altieri, K., Kreidenweis, S., and Feingold, G.: Secondary organic aerosol yields from cloudprocessing of isoprene oxidation products, Geophys. Res. Lett., 35, L02816, doi:10.1029/2007GL031828, 2008.

Fredenslund, A., Jones, R., and Prausnitz, J.: Group-contribution estimation of activity-coefficients in nonideal liquid-mixtures, AIChE J., 21, 1086-1099, 1975.

Gao, S., Ng, N. L., Keywood, M., Varutbangkul, V., Bahreini, R., Nenes, A., He, J., Yoo, K. Y., Beauchamp, J. L., Hodyss, R. P., Flagan, R. C., and Seinfeld, J. H.: Particle phase acidity and oligomer formation in secondary organic aerosol, Environ. Sci. Technol., 38, 6582-6589, doi:10.1021/es049125k, 2004.

Goliff, W. and Stockwell, W.: The Regional Atmospheric Chemistry Mechanism, version 2, an update, International Conference on Atmospheric Chemical Mechanisms, University of California, Davis, CA, USA, available at: http://airquality.ucdavis.edu/ pages/events/2008/acm/Goliff.pdf (last access: August 2010), 2008.

Guenther, A., Karl, T., Harley, P., Wiedinmyer, C., Palmer, P., and Geron, C.: Estimates of global terrestrial isoprene emissions using MEGAN (Model of Emissions of Gases and Aerosols from Nature), Atmos. Chem. Phys., 6, 3181-3210, doi:10.5194/ acp-6-3181-2006, 2006.

Hilal, S., Ayyampalayam, S., and Carreira, L.: Air-liquid partition coefficient for a diverse set of organic compounds: Henry's law constant in water and hexadecane, Environ. Sci. Technol., 42, 9231-9236, doi:10.1021/es8005783, 2008.

Jang, M., Czoschke, N. M., Lee, S., and Kamens, R.: Heterogeneous atmospheric aerosol production by acid-catalysed particlephase reactions, Science, 298, 814-817, doi:10.1126/science. 1075798, 2002.

Jang, M., Czoschke, N. M., and Northcross, A. L.: Semiempirical model for organic aerosol growth by acid-catalyzed heterogeneous reactions of organic carbonyls, Environ. Sci. Technol., 39, 164-174, doi:10.1021/es048977h, 2005.

Kamens, R., Gery, M., Jeffries, H., Jacksons, M., and Cole, E.: Ozone-isoprene reactions: product formation and aerosol potential, Int. J. Chem. Kinet., 14, 955-975, 1982.

Kanakidou, M., Seinfeld, J., Pandis, S., Barnes, I., Dentener, F., Facchini, M., Van Dingenen, R., Ervens, B., Nenes, A., Nielsen, C., Swietlicki, E., Putaud, J., Balkanski, Y., Fuzzi, S., Horth, J., Moortgat, G., Winterhalter, R., Myhre, C., Tsigaridis, K., Vignati, E., Stephanou, E., and Wilson, J.: Organic aerosol and global climate modelling: a review, Atmos. Chem. Phys., 5, 1053-1123, doi:10.5194/acp-5-1053-2005, 2005.

Kim, Y., Sartelet, K., and Seigneur, C.: Comparison of two gas-phase chemical kinetic mechanisms of ozone formation over Europe, J. Atmos. Chem., 62, 89-119, doi:10.1007/ s10874-009-9142-5, 2009.

Kleindienst, T., Lewandowski, M., Offenberg, J., Jaoui, M., and Edney, E.: Ozone-isoprene reactions: Re-examination of the formation of secondary organic aerosol, Geophys. Res. Lett., 34 L01805, doi:10.1029/2006GL027485, 2007.

Kleindienst, T., Lewandowski, M., Offenberg, J., Jaoui, M., and Edney, E.: The formation of secondary organic aerosols from the isoprene $+\mathrm{OH}$ reaction in the absence of $\mathrm{NO}_{\mathrm{X}}$, Atmos. Chem. Phys., 9, 6541-6558, doi:10.5194/acp-9-6541-2009, 2009.

Kroll, J., Ng, N., Murphy, S., Flagan, R., and Seinfeld, J.: Secondary organic aerosol formation from isoprene photooxidation, Environ. Sci. Technol., 40, 1869-1877, doi:10.1021/es0524301, 2006.

Kroll, J. H. and Seinfeld, J. H.: Chemistry of secondary organic aerosol: Formation and evolution of low-volatility organics in the atmosphere, Atmos. Environ., 42, 3593-3624, doi:10.1016/j. atmosenv.2008.01.003, 2008.

Liggio, J., Li, S.-M., and McLaren, R.: Heterogeneous Reactions of Glyoxal on Particulate Matter: Identification of Acetals and Sulfate Esters, Environ. Sci. Technol., 39, 1532-1541, doi:10. 1021/es048375y, 2005.

Meylan, W. and Howard, P.: Bond contribution method for estimating Henry's law constants, Environ. Toxicol. Chem, 10, 12831293, doi:10.1002/etc.5620101007, 1991.

Meylan, W. and Howard, P.: SRC's EPI suite, v3.20, Tech. rep., Syracuse Research Corporation, 2000.

Ng, N. L., Chhabra, P. S., Chan, A. W. H., Surratt, J. D., Kroll, J. H., Kwan, A. J., McCabe, D. C., Wennberg, P. O., Sorooshian, A., Murphy, S. M., Dalleska, N. F., Flagan, R. C., and Seinfeld, J. H.: Effect of $\mathrm{NO}_{\mathrm{x}}$ level on secondary organic aerosol (SOA) formation from the photooxidation of terpenes, Atmos. Chem. Phys., 7, 5159-5174, doi:10.5194/acp-7-5159-2007, 2007a.

Ng, N. L., Kroll, J. H., Chan, A. W. H., Chhabra, P. S., Flagan, R. C., and Seinfeld, J. H.: Secondary organic aerosol formation from m-xylene, toluene, and benzene, Atmos. Chem. Phys., 7, 3909-3922, doi:10.5194/acp-7-3909-2007, 2007b.

Ng, N., Kwan, A., Surratt, J., Chan, A., Chhabra, P., Sorooshian, A., Pye, H., Crounse, J., Wennberg, P., Flagan, R., and Seinfeld, J.: Secondary organic aerosol (SOA) formation from reaction of isoprene with nitrate radicals $\left(\mathrm{NO}_{3}\right)$, Atmos. Chem. Phys., 8 , 4117-4140, doi:10.5194/acp-8-4117-2008, 2008.

Nguyen, T., Bateman, A., Bones, D., Nizkorodov, S., Laskin, J., and Laskin, A.: High-resolution mass spectrometry analysis of secondary organic aerosol generated by ozonolysis of isoprene, Atmos. Environ., 44, 1032-1042, doi:10.1016/j.atmosenv.2009. 12.019, 2010.

Odum, J., Hoffman, T., Bowman, F., Collins, D., Flagan, R. and Seinfeld, J.: Gas/particle partitioning and secondary organic aerosol yields, Environ. Sci. Technol., 30, 2580-2585, doi: 10.1021/es950943+, 1996

Pandis, S., Paulson, S., Seinfeld, J., and Flagan, R.: Aerosol formation in the photooxidation of isoprene and $\beta$-pinene, Atmos. Environ., 25, 997-1008, doi:10.1021/es0524301, 1991.

Pankow, J.: An absorption model of gas/particle partitioning of organic compounds in the atmosphere, Atmos. Environ., 28A, 185188, 1994a.

Pankow, J.: An absorption model of the gas/aerosol partitioning involved in the formation of secondary organic aerosol, Atmos. 
Environ., 28A, 189-193, 1994b.

Pankow, J. and Asher, W.: SIMPOL.1: a simple group contribution method for predicting vapor pressures and enthalpies of vaporization of multifunctional organic compounds, Atmos. Chem. Phys., 8, 2773-2796, doi:10.5194/acp-8-2773-2008, 2008.

Pöschl, U., Von Kuhlmann, R., Poisson, N., and Crutzen, P.: Development and intercomparison of condensed isoprene oxidation mechanisms for global atmospheric modeling, J. Atmos. Chem., 37, 29-52, doi:10.1023/A:1006391009798, 2000.

Pun, B.: Development and initial application of the sesquiversion of MADRID, J. Geophys. Res., 113, D12212, doi:10.1029/ 2008JD009888, 2008.

Pun, B. and Seigneur, C.: Investigative modeling of new pathways for secondary organic aerosol formation, Atmos. Chem. Phys., 7, 2199-2216, doi:10.5194/acp-7-2199-2007, 2007.

Pun, B., Griffin, R., Seigneur, C., and Seinfeld, J.: Secondary organic aerosol 2. Thermodynamic model for gas/particle partitioning of molecular constituents, J. Geophys. Res., 107, 4333, doi:10.1029/2001JD000542, 2002.

Pun, B., Wu, S.-Y., Seigneur, C., Seinfeld, J., Griffin, R., and Pandis, S.: Uncertainties in Modeling Secondary Organic Aerosols: Three-Dimensional Modeling Studies in Nashville/Western Tennessee, Environ. Sci. Technol., 37, 3647-3661, doi:10.1021/ es0341541, 2003.

Pun, B., Seigneur, C., and Lohman, K.: Modeling secondary organic aerosol formation via multiphase partitioning with molecular data, Environ. Sci. Technol., 40, 4722-4731, doi:10.1021/ es0522736, 2006.

Raventos-Duran, T., Camredon, M., Valorso, R., and Aumont, B.: Structure-activity relationships to estimate the effective Henry's law coefficients of organics of atmospheric interest, Atmos. Chem. Phys. Discuss., 10, 4617-4647, doi:10.5194/ acpd-10-4617-2010, 2010.

Rollins, W., Kiender-Scharr, A., Fry, J., Brauers, T., Brown, S., Dorn, H.-P., Dubé, W., Fuchs, H., Mensah, A., Mentel, T., Tillmann, R., Wegener, R., Wooldridge, P., and Cohen, R.: Isoprene oxidation by nitrate radical: alkyl nitrate and secondary organic aerosol yields, Atmos. Chem. Phys., 9, 6685-6703, doi: 10.5194/acp-9-6685-2009, 2009.

Ruppert, L. and Becker, K.: A product study of the $\mathrm{OH}$ radical-initiated oxidation of isoprene: formation of $\mathrm{C}_{5^{-}}$ unsaturated diols, Atmos. Environ., 34, 1529-1542, doi:10.1016/ S1352-2310(99)00408-2, 2000.

Surratt, J., Murphy, S., Kroll, J., Ng, N., Hildebrandt, L., Sorooshian, A., Szmigielski, R., Vermeylen, R., Maenhaut, W., Claeys, M., Flagan, R., and Seinfeld, J.: Chemical composition of secondary organic aerosol formed from the photooxidation of isoprene, J. Phys. Chem. A, 110, 9665-9690, doi: 10.1021/jp061734m, 2006.
Surratt, J., Chan, A., Eddingsaas, N., Chan, M., Loza, C., Kwan, A., Hersery, S., Flagan, R., Wennberg, P., and Seinfeld, J.: Reactive intermediates revealed in secondary organic aerosol formation from isoprene, Proc. Natl. Acad. Sci., 107, 6640-6645, doi:10. 1073/pnas.0911114107, 2010.

Suzuki, T., Ohtaguchi, K., and Koide, K.: Application of principal components analysis to calculate Henry's constant from molecular structure, Computers Chem., 16, 41-52, 1992.

Verwer, J., Spee, E., Bloom, J., and Hundsdorfer, W.: A secondorder rosenbrock method applied to photochemical dispersion problems, SIAM J. Sci. Comput., 20, 1456-1480, doi:10.1137/ S1064827597326651, 1999.

Volkamer, R., Ziemann, P. J., and Molina, M. J.: Secondary Organic Aerosol Formation from Acetylene $\left(\mathrm{C}_{2} \mathrm{H}_{2}\right)$ : seed effect on SOA yields due to organic photochemistry in the aerosol aqueous phase, Atmos. Chem. Phys., 9, 1907-1928, doi:10.5194/ acp-9-1907-2009, 2009.

Yu, S., Bhave, P., Dennis, R., and Marthur, R.: Seasonal and regional variations of primary and secondary organic aerosols over the Continental United States: Semi-empirical estimates and model evaluation, Environ. Sci. Technol., 41, 4690-4697, doi: 10.1021/es061535g, 2007.

Zhang, Q., Jimenez, J., Canagaratna, M., Allan, J., Coe, H., Ulbrich, I., Alfarra, M., Takami, A., Middlebrook, A., Sun, Y., Dzepina, K., Dunlea, E., Docherty, K., De-Carlo, P., Salcedo, D., Onasch, T., Jayne, J., Miyoshi, T., Shimono, A., Hatakeyama, S., Takegawa, N., Kondo, Y., Schneider, J., Drewnick, F., Borrmann, S., Weimer, S., Demerjian, K., Williams, P., Bower, K., Bahreini, R., Cottrell, L., Griffin, R., Rautiainen, J., Sun, J., Zhang, Y., and Worsnop, D.: Ubiquity and dominance of oxygenated species in organic aerosols in anthropogenically-influence Northern Hemisphere mildlatitudes, Geophys. Res. Lett., 34, doi: 10.1029/2007GL029979, 2007a.

Zhang, Y., Huang, J.-P., Henze, D., and Seinfeld, J.: Role of isoprene in secondary organic aerosol formation on a regional case, J. Geophys. Res., 112, D20 207, doi:10.1029/2007JD008675, 2007b.

Zuend, A., Marcolli, C., Peter, T., and Seinfeld, J. H.: Computation of liquid-liquid equilibria and phase stabilities: implications for RH-dependent gas/particle partitioning of organicinorganic aerosols, Atmos. Chem. Phys., 10, 7795-7820, doi: doi:10.5194/acpd-10-12497-2010, 2010. 